\title{
Synaptic Kainate Receptors Tune Oriens-Lacunosum Moleculare Interneurons to Operate at Theta Frequency
}

\author{
Miri Goldin, Jérôme Epsztein, Isabel Jorquera, Alfonso Represa, Yehezkel Ben-Ari, Valérie Crépel, and Rosa Cossart \\ Institut de Neurobiologie de la Méditeranée, Inserm, Unité 29, Université de la Méditerranée, Parc Scientifique de Luminy, 13273 Marseille cedex 9, France
}

\begin{abstract}
GABAergic interneurons of the hippocampus play an important role in the generation of behaviorally relevant network oscillations. Among this heterogeneous neuronal population, somatostatin (SOM)-positive oriens-lacunosum moleculare (0-LM) interneurons are remarkable because they are tuned to operate at theta frequencies $(6-10 \mathrm{~Hz})$ in vitro and in vivo. Recent studies show that a high proportion of glutamatergic synapses that impinge on 0-LM interneurons are mediated by kainate receptors (KA-Rs). In the present study, we thus tested the hypothesis that KA-Rs transmit afferent inputs in 0-LM neurons during synaptic stimulation at theta frequency. We combined multibeam two-photon calcium imaging in hippocampal slices from SOM-enhanced green fluorescent protein (EGFP) mice, to record the activity of SOM cells as well as hundreds of neurons simultaneously, and targeted electrophysiological recordings and morphological analysis to describe the morphofunctional features of particular cells. We report that EGFP-positive 0-LM neurons are the only subtype of interneuron that reliably follows synaptic stimulation of the alveus in the theta frequency range. Electrophysiological recordings revealed the crucial contribution of KA-Rs to the firing activity and to the glutamatergic response to theta stimuli in 0-LM cells compared with other cell types. The reliable activation of O-LM cells in the theta frequency range did not simply result from the longer kinetics of KA-R-mediated postsynaptic events $\left(\mathrm{EPSP}_{\mathrm{KA}}\right.$ ) but presumably from a specific interaction between $\mathrm{EPSP}_{\mathrm{KA}}$ and their intrinsic active membrane properties. Such preferential processing of excitatory inputs via KA-Rs by distally projecting GABAergic microcircuits could provide a key role in theta band frequency oscillations.
\end{abstract}

Key words: kainate; 0-LM; theta; imaging; interneuron; network

\section{Introduction}

GABAergic cells control the generation of network oscillations (Cobb et al., 1995; Freund and Buzsáki, 1996; Whittington et al., 1997; McBain and Fisahn, 2001; Klausberger et al., 2003; Whittington and Traub, 2003; Somogyi and Klausberger, 2005). A central issue is to understand how different GABAergic circuits integrate ongoing activity to generate behaviorally relevant oscillations. Recent studies suggested that the integrative properties of interneurons are strongly influenced by their synaptic inputs (Pouille and Scanziani, 2004; Oren et al., 2006). Glutamatergic synaptic transmission is principally mediated by AMPA receptors, but kainate receptors (KA-Rs) also play a central role (Castillo et al., 1997; Vignes and Collingridge, 1997; Cossart et al., 1998, 2002; Frerking et al., 1998; Bureau et al., 1999) although in a manner that is remarkably cell specific (Ben Ari and Cossart, 2000; Lerma, 2003). Various types of interneurons express KA-Rs (Cossart et al., 1998, 2002; Frerking et al., 1998; Mulle et al., 2000;

Received 0ct. 11, 2006; revised June 25, 2007; accepted June 26, 2007.

This work was supported by grants from Inserm, the Ville de Marseille and Region Provence Alpes Côte d'Azur, and Fondation pour la Recherche sur le Cerveau. R.C. and A.R. were supported by Centre National de la Recherche Scientifique. M.G. was supported by Fondation pour la Recherche Médicale and the Marie Curie Fellowship. We thank L. Sasportas and C. Allène for their participation in Neurolucida reconstructions. We thank D. Aronov for designing the imaging data analysis software.

Correspondence should be addressed to Dr. Rosa Cossart, Institut de Neurobiologie de la Méditerranée, Inserm Unité 29, Parc Scientifique de Luminy, Boîte Postale 13, 13273 Marseille cedex 9, France. E-mail: cossart@inmed.univ-mrs.fr.

DOI:10.1523/JNEUROSCI.1237-07.2007

Copyright $\odot 2007$ Society for Neuroscience $\quad$ 0270-6474/07/279560-13\$15.00/0
Ali, 2003; Lerma, 2003); however, the distribution of KA-Roperated synaptic transmission among GABAergic cells is still unknown. This is important in view of the slower kinetics of KAversus AMPA-R-mediated EPSCs (Frerking et al., 1998; Cossart et al., 2002), which could enable the generation of oscillations with different dominating frequencies (Frerking and OhligerFrerking, 2002). Therefore, the KA-R subtype is well suited to mediate cell-specific temporal information processing in interneurons, but its functional distribution and precise conditions of activation remain to be determined.

We addressed this issue using multibeam two-photon microscopy, on-line analysis, and electrophysiology, to record electrically evoked network dynamics and describe the distribution of active cells (Cossart et al., 2005). We concentrated on CA1 somatostatin-expressing stratum oriens interneurons and specifically on oriens-lacunosum moleculare (O-LM) cells, the predominant horizontal cell type in this layer (Ali and Thomson, 1998; Maccaferri, 2005). These neurons participate in hippocampal theta activity in vivo (Buzsaki, 2002; Klausberger et al., 2003) and in vitro (Pike et al., 2000; Gillies et al., 2002; Hajos et al., 2004; Gloveli et al., 2005). They also receive a large input mediated by KA-Rs (Cossart et al., 2002). To target this subpopulation, we used transgenic mice expressing enhanced green fluorescent protein (EGFP mice) in a subset of somatostatin-containing interneurons [EGFP-positive $\left(\mathrm{EGFP}^{+}\right)$] that mostly comprise O-LM cells in the CA1 stratum oriens (Oliva et al., 2000). We report that O-LM neurons reliably follow theta stimulation (TS) of the 
alveus, an effect selectively mediated by KA-R synaptic activation. Stratum oriens interneurons that did not follow theta stimulation via $\mathrm{KA}-\mathrm{R}$ activation were perisomatic $(\mathrm{O}-\mathrm{P})$, bistratified $(\mathrm{O}-\mathrm{Bi})$, or septum/back-projecting (O-S/BP) cells but not O-LM neurons. Electrophysiological recordings from EGFP-positive/ O-LM neurons showed that postsynaptic KA-Rs contribute to action potential firing at $10 \mathrm{~Hz}$ during theta stimulations. Shortterm facilitation or summation of the postsynaptic response in O-LM cells were not observed in the theta frequency range. The reliable activation of O-LM cells by theta frequency stimulations did not simply result from the longer kinetics of KA-R-operated synaptic transmission but presumably from a specific interaction between the postsynaptic response and intrinsic membrane properties. These findings should support the recruitment of O-LM cells during hippocampal theta activity and provide a synaptic framework for the mechanisms driving theta rhythms.

\section{Materials and Methods}

Slice preparation and two-photon imaging. Transverse hippocampal slices (350 $\mu \mathrm{m}$ thick) were prepared from 12- to 17-d-old transgenic mice expressing EGFP in somatostatin-containing neurons (Oliva et al., 2000) using a Microm (Walldorf, Germany) tissue slicer (Microtome HM $650 \mathrm{~V})$ with ice-cold oxygenated modified artificial CSF (ACSF) $(0.5 \mathrm{~mm}$ $\mathrm{CaCl}_{2}$ and $7 \mathrm{mM} \mathrm{MgSO}_{4}$ and in which $\mathrm{NaCl}$ was replaced by an equimolar concentration of choline). Slices were then transferred for rest $(\sim 1 \mathrm{~h})$ at room temperature in oxygenated regular ACSF containing the following (in mM): $126 \mathrm{NaCl}, 3.5 \mathrm{KCl}, 1.2 \mathrm{NaH}_{2} \mathrm{PO}_{4}, 26 \mathrm{NaHCO}_{3}, 1.3 \mathrm{MgCl}_{2}, 2.0$ $\mathrm{CaCl}_{2}$, and 10 D-glucose, $\mathrm{pH}$ 7.4. For AM loading, slices were incubated in a small vial containing $2.5 \mathrm{ml}$ of oxygenated ACSF with $25 \mu \mathrm{l}$ of a $1 \mathrm{~mm}$ fura-2 AM solution (in 100\% DMSO; Invitrogen, Carlsbad, CA) for 20-30 min. Slices were incubated in the dark, and the incubation solution was maintained at $35-37^{\circ} \mathrm{C}$. Experiments were performed at $30-$ $32^{\circ} \mathrm{C}$ with regular ACSF and continuously aerated with $95 \% \mathrm{O}_{2} / 5 \% \mathrm{CO}_{2}$. Imaging was performed with a multibeam two-photon LASER scanning system (Trimscope; La Vision Biotec, Bielefeld, Germany) coupled to an Olympus Optical (Hamburg, Germany) microscope. This system is based on a patented beam splitter that splits up the incoming femtosecond LASER beam (provided by a titanium:sapphire LASER source; Chameleon; Coherent, Santa Clara, CA), into 64 beamlets, which are scanned simultaneously in the slice. This results in 64 times higher image acquisition rates compared with conventional multiphoton scanning microscopes. Images were acquired through a CCD camera (Imager $3 \mathrm{QE}$; La Vision Biotec). Acquisition frequency was between 150 and $210 \mathrm{~ms}$ per frame. Slices were imaged using a low-magnification, high numerical aperture (NA) objective (20×, NA 0.95; Olympus Optical). The size of the imaged field was typically $\sim 430 \times 380 \mu^{2}$. Calcium and GFP fluorescence signals were separated by the excitation wavelength of the LASER source (780 and $900 \mathrm{~nm}$, respectively).

Electrical stimulation. Axons of CA1 pyramidal cells were stimulated via a custom-made bipolar NiCh electrode (model 762000; A-M Systems, Sequim, WA) placed $\sim 100 \mu \mathrm{m}$ from the imaged region in the alveus (intensity of 5-10 $\mu \mathrm{A}, 50 \mu \mathrm{s}$ ). A Grass Instrument (Qunicy, MA) stimulation unit was used (model SIU5B). The TS protocol included 10 stimuli delivered at a frequency of $10 \mathrm{~Hz}$ every $30 \mathrm{~s}$. Action potential firing triggered by antidromic activation resulting from the direct stimulation of the cell membrane by the electrode was discarded from the analysis. Antidromically evoked calcium events, i.e., events that were not blocked by antagonists of ionotropic GABAergic and glutamatergic transmission, were also systematically discarded.

Analysis. Analysis was performed with custom-made software in Matlab (MathWorks, Natick, MA) written by D. Aronov (Massachusetts Institute of Technology, Cambridge, MA). We developed a program aimed at the automatic identification of loaded hippocampal cells and at measuring their fluorescence as a function of time. This program is an improved version of the previously designed software for cortical slices analysis (Cossart et al., 2003). We encountered two major problems for an automatic identification of cells in an image: (1) variations in back- ground fluorescence, which precluded the use of a uniform threshold value throughout the image, and (2) the inability of a simple thresholding procedure to separate nearby cells. The latter problem was especially severe in the dense pyramidal cell layer of the hippocampus. As before (Cossart et al., 2003), we solved the problem of background variations by normalizing each pixel by the average fluorescence in its vicinity. We also convolved the image with a two-dimensional Gaussian $(\sigma=6 \mu \mathrm{m})$, which emphasized circular neuronal shapes and partially separated nearby neurons. A threshold (usually top 10 percentile of the overall pixel fluorescence distribution) was applied to the image to separate cell contours from the background. To complete the separation of nearby cells, we measured a circularity threshold for every contour, defined as $c=$ $P^{2} /(4 A)$, where $P$ is the perimeter and $A$ is the area of a contour. High values of $c$ (usually $>4$ ) identified highly noncircular shapes usually indicative on unseparated cell contours. Local fluorescence maxima were identified within such contours, and the contours were separated into a corresponding number of concave shapes. All image processing was performed on time averages of recorded movies. The calcium signal of each cell was the average fluorescence within the contour of that cell, measured as a function of time. Signal processing algorithms from the MiniAnalysis software (Synaptosoft, Decatur, GA) were used to detect automatically the onsets and offsets (time of half-amplitude decay) of calcium signals within the traces of individual cells. Calcium changes below 5\% DF/F were discarded because calibration of the imaging system showed that, on average, a single action potential will produce a fluorescence change always above this value (average DF/F, $6.5 \pm 0.5 \%$ ). The entire procedure could be performed on-line sufficiently quickly to identify cells for targeted patchclamp recordings. However, fluorescence traces were also visually scanned off-line to correct for the detection of false positives. A significant calcium response to a TS is an event that passed the threshold for detection within a $400 \mathrm{~ms}$ time window after the time of the stimuli. The analysis was performed separately for each hippocampal layer, with the borders between layers drawn manually.

Electrophysiology. Slices from EGFP mice were prepared as for imaging except that a few recordings were also performed in 1-month-old animals $(n=3)$. Interneurons recorded for miniature glutamatergic activity analysis were visualized by infrared video microscopy using an upright Zeiss (Le Pecq, France) microscope equipped with a $40 \times$ water immersion objective. Fluorescent interneurons were identified with a UV lamp (xenon, excitation filter 470/40) and recorded using a pipette solution containing: (1) in voltage-clamp mode, $120 \mathrm{~mm}$ Cs-gluconate, $10 \mathrm{~mm}$ $\mathrm{MgCl}_{2}, 0.1 \mathrm{~mm} \mathrm{CaCl}, 1 \mathrm{~mm}$ EGTA, $5 \mathrm{~mm} \mathrm{Na}_{2}$ adenosine triphosphate, 10 mM HEPES, and $0.5 \%$ biocytin; (2) in current-clamp mode, $130 \mathrm{~mm}$ K-methylSO, 5 mм KCl, 5 mм NaCl, 10 mм HEPES, 2.5 mм Mg-ATP, $0.3 \mathrm{~mm}$ GTP, and $0.5 \%$ biocytin. The osmolarity was $265-275 \mathrm{mOsm}, \mathrm{pH}$ 7.3. Microelectrodes had a resistance of $4-8 \mathrm{M} \Omega$. Uncompensated series resistances were, on average, $14 \mathrm{M} \Omega$.

Signals were fed to an EPC10 (HEKA Elektronik, Heidelberg, Germany), filtered $(3 \mathrm{kHz})$, digitized $(10 \mathrm{kHz})$ with a Labmaster interface card to a personal computer, and acquired using Axoscope 7.0 software (Molecular Devices, Union City, CA). Data was analyzed with MiniAnalysis 5.1 program (Synaptosoft). Spontaneous glutamatergic currents were measured at $-60 \mathrm{mV}$ and miniature EPSC (mEPSCs) were recorded in the presence of TTX $(1 \mu \mathrm{M})$, bicuculline $(10 \mu \mathrm{M})$, and D-APV $(40 \mu \mathrm{M})$. Addition of GYKI 52466 [4-(8-methyl-9H-1,3-dioxolo [4,5h] [2,3] benzodiazepin-5-yl)-benzenamine hydrochloride] $(100 \mu \mathrm{M})$ or 2,3-dihydroxy-6-nitro-7-sulfonyl-benzo[f]quinoxaline (NBQX) (1 $\mu \mathrm{M})$ blocked AMPA-R-mediated-mEPSCs ( mEPSC $_{\text {AMPA }}$ ), and further addition of CNQX $(50 \mu \mathrm{M})$ blocked all mEPSCs. Single and averaged events (200 events per cell) were fully characterized: rise times (10-90\%), amplitudes, and decay time constants were calculated.

Kinetic analysis. Identification of KA-R-mediated-mEPSCs ( mEPSC $_{\mathrm{KA}}$ ) and $\mathrm{MEPSC}_{\mathrm{AMPA}}$ was based on their kinetics profile (Cossart et al., 2002). Briefly, spontaneous $\mathrm{mEPSC}_{\mathrm{AMPA} / \mathrm{KA}}$ (in the presence of $1 \mu \mathrm{M}$ TTX, 10 $\mu \mathrm{M}$ bicuculline, and $40 \mu \mathrm{M} \mathrm{D}-\mathrm{APV}$ ) were recorded from CA1 stratum oriens interneurons, and each single event was fully characterized by the following parameters: rise time (10-90\%), amplitude, charge (area under EPSCs), and decay time constants. In control conditions, two types of mEPSCs could be distinguished based on the time course of their decay: 
fast and slow. After $10 \mathrm{~min}$ application of AMPA-R antagonists $(100 \mu \mathrm{M}$ GYKI 52466 or $1 \mu \mathrm{M}$ NBQX), fast events were abolished and only KA-Rmediated events with a slower time course and a small amplitude remained. Slow events were blocked by SYM 2081 [(2S,4R)-4methylglutamic acid], a functional antagonist for KA-Rs that required 15 min drug application. Decay times of slow events in control and mEP$\mathrm{SC}_{\mathrm{KA}}$ left after blocking $\mathrm{mEPSC}_{\mathrm{AMPA}}$ had the same kinetics $(n=17$ interneurons; one-way ANOVA, $p>0.05$ ), demonstrating that slow kinetics events were KA-R mediated. To separate fast IEPSC $_{\mathrm{AMPA}}$ from slow mEPSC $_{\mathrm{KA}}$, a "kinetic limit" was determined. Events were individually fitted, and decay times were plotted versus rise times and versus amplitudes. Fast $\mathrm{mEPSC}_{\mathrm{AMPA}}$ and slow $\mathrm{mEPSC}_{\mathrm{KA}}$ clustered in two distinct areas of these scattered plots. Limits to segregate between the two populations of events were as follows: $\mathrm{mEPSC}_{\mathrm{AMPA}}$, rise-time $<1 \mathrm{~ms}$ and decay time $<4 \mathrm{~ms} ; \mathrm{mEPSC}_{\mathrm{KA}}$, rise time $>1 \mathrm{~ms}$ and decay time $>4 \mathrm{~ms}$.

Pharmacology. Bicuculline, NBQX, D-APV, CNQX, GYKI 52466, and SYM 2081 were purchased from Tocris (Ellisville, MO), TTX was from Latoxan (Valence, France), and CX546 [1-(1,4-benzodioxan-6ylcarbonyl) piperidine] was from Sigma-Aldrich (Lyon, France).

Morphology. Slices were processed for the detection of biocytin-filled neurons according to a previously established procedure (Cossart et al., 2006). Briefly, slices were fixed overnight at $4^{\circ} \mathrm{C}$ in a solution containing $4 \%$ paraformaldehyde in $0.1 \mathrm{~m}$ phosphate buffer (PB), pH 7.4. After fixation, slices were rinsed in PB, cryoprotected in sucrose (30\% in PBS), and quickly frozen on dry ice. To neutralize endogenous peroxidase, slices were pretreated for $30 \mathrm{~min}$ in $1 \% \mathrm{H}_{2} \mathrm{O}_{2}$. After several rinses in 0.01 м PBS, $\mathrm{pH} 7.4$, slices were incubated for $24 \mathrm{~h}$ at room temperature, in 1:100 avidin-biotin peroxidase complex (Vector Laboratories, Burlingame, CA) diluted in PBS containing 0.3\% Triton X-100. After $30 \mathrm{~min}$ rinses in PBS, slices were processed with $0.04 \% 3-3^{\prime}$-diaminobenzidine$\mathrm{HCl}$ (Sigma, St. Louis, $\mathrm{MO}$ ) and $0.006 \% \mathrm{H}_{2} \mathrm{O}_{2}$ diluted in PBS. Seventyeight biocytin-filled interneurons were identified. Among these 78 interneurons, we could obtain both a complete characterization of mEPSCs/ EPSPs and a complete axonal and dendritic labeling from 72 interneurons. Neurons were classified based on previously established morphological criteria. We classified as O-S/BP interneurons with axonal branches invading the CA3 region (stratum oriens and/or stratum radiatum) and possibly the dentate gyrus and/or axonal branches traveling through the alveus and reaching the fimbria (see Figs. 3, 7). This population is likely to comprise at least two different cell types (i.e., septum and BP interneurons) that essentially differ by their septal innervation. We decided to group them because both were shown to innervate specifically GABAergic interneurons in the hippocampus (Gulyas et al., 2003) and because they are hardly morphologically differentiable in hippocampal slices: they display an axonal arborization that crosses subfield boundaries and sparsely spiny dendrites (a property that distinguishes them from O-LM cells with a cut axon). These interneurons were reconstructed for morphometric analysis with a computer-assisted system (Neurolucida; MicroBrightField, Williston, VT) attached to a Nikon (Tokyo, Japan) microscope.

\section{Results}

\section{CA1 stratum oriens EGFP-positive cells are activated by theta stimulation}

We used multibeam two-photon imaging in hippocampal slices from EGFP mice, loaded with a calcium indicator to determine the network dynamics evoked by repetitive $(30 \mathrm{~s}$ interval) electrical TS (train of 10 stimuli at $10 \mathrm{~Hz}$; see Materials and Methods). Stimulation electrodes were placed in the alveus $\sim 100 \mu \mathrm{m}$ away from the imaged area (Fig. 1). Activity was monitored in hundreds of neurons simultaneously, spanning across all CA1 hippocampal layers. We performed automated signal processing with custom-made software to obtain raster plots describing the activity of all neurons imaged as a function of time (Figs. 1, 2). A 5\% DF/F amplitude threshold was chosen for calcium signal detection (more than five times larger than the noise SD) because calibration of the imaging
A

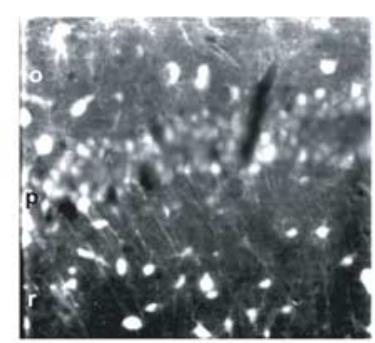

C



E

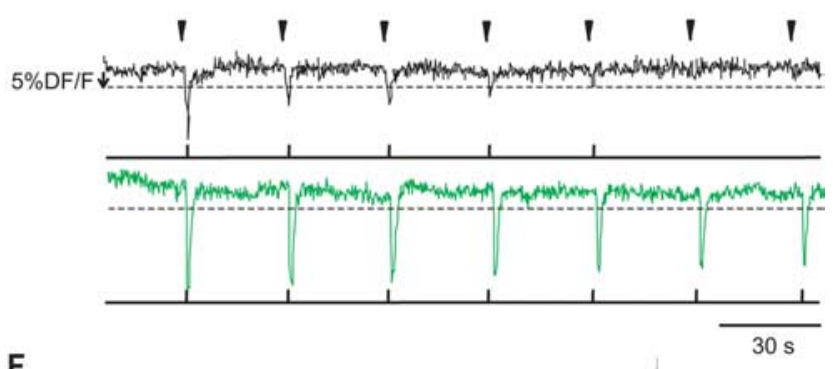

$\mathbf{F}$
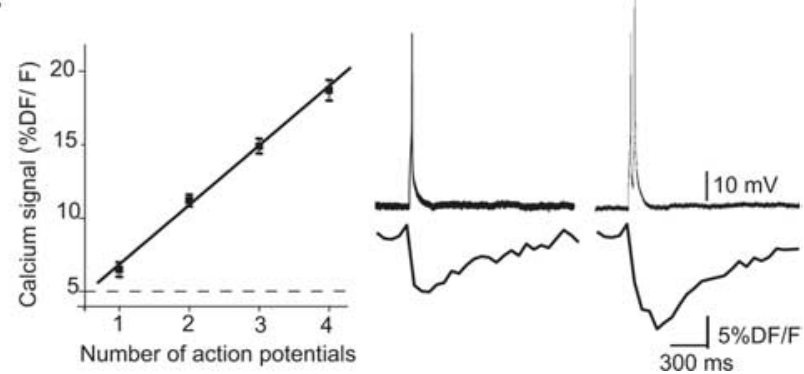

Figure 1. Imaging evoked network dynamics in the CA1 region from somatostatin-EGFP mice. $A$, Two-photon calcium fluorescence image of the CA1 region from an EGFP mouse hippocampal slice at

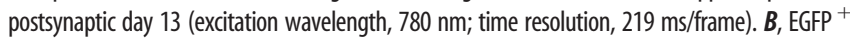
neurons were identified within the same slice (excitation wavelength, $900 \mathrm{~nm}$ ). C, Automatically detected contours of the cells imaged above; green filled contours indicate EGFP ${ }^{+}$neurons. Dashed lines specify layer borders. o, Stratum oriens; $r$, stratum radiatum; $p$, stratum pyramidale. Scale bar, $100 \mu \mathrm{m} . \boldsymbol{D}$, Schematicdrawing of the experimental setup indicating the imaged area in CA1 (dashed), the positions of the recording patch pipette (in the oriens), and of the stimulating electrode (in the alveus, outside the field of the imaged frame); slices were activated with the TS protocol (trains of 10 stimuli at $10 \mathrm{~Hz}$ every $30 \mathrm{~s})$. $\boldsymbol{E}$, Trace of the average calcium fluorescence change in single EGFP(black) and EGFP ${ }^{+}$(green) cells during a TS protocol. Detected calcium responses correspond to relative fluorescence changes with amplitude above $5 \% D F / F$ as shown in the corresponding raster plots. Each arrow indicates a train of 10 stimuli at $10 \mathrm{~Hz}$. F, Correlation between the amplitude of the calcium signal and evoked action potentials. Left graph plots the amplitude of the evoked calcium signal as a function of the number of action potentials evoked by depolarizing current steps in a CA1 stratum oriens interneuron. Right traces show current-clamp recordings and simultaneously recorded calcium fluorescence changes (same imaging conditions as in $\boldsymbol{A}$ ) resulting from one and two evoked action potentials. The dashed line indicates the $5 \% \mathrm{DF} / F$ threshold used for automatic event detection. Error bars indicate SEMs.

system showed that a single action potential produced, on average, a fluorescence change always above this value (Fig. 1) (see Materials and Methods). Detected calcium events were indeed dependent on action potential firing because they were 
A

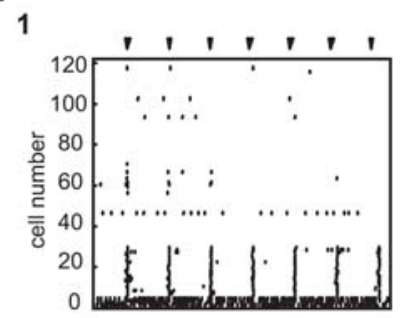

\section{2}

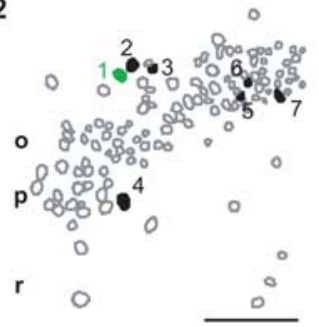

B 1

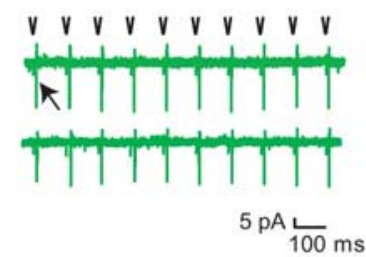

2
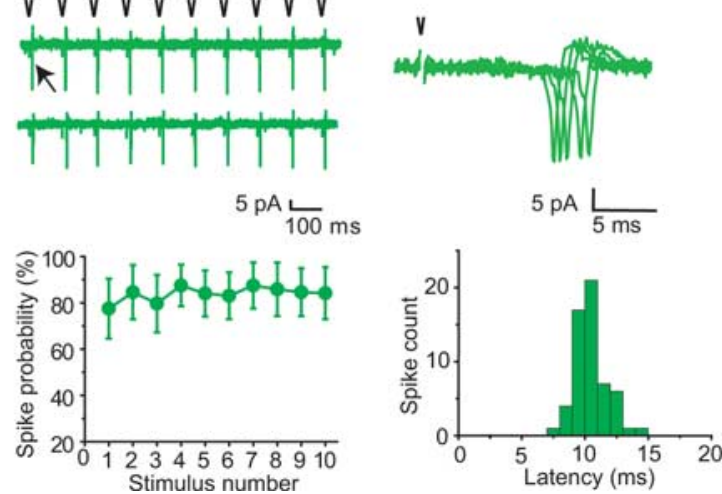

Figure 2. EGFP-positive neurons preferentially respond to theta stimulation. $\boldsymbol{A}$ 1, Raster plot of the activity from a movie; filled arrows mark the TS stimulation times. Each row represents the activity within a cell, and each dot represents the onset of a calcium transient. Antidromically activated neurons were discarded. $\mathbf{A 2}$, Contour plot of the neurons that fluorescence traces are shown in A3 (black filled). Green filled contour indicates a EGFP ${ }^{+}$neuron. Scale bar, $100 \mu \mathrm{m}$. A3, Representative calcium fluorescence traces during a TS protocol in control conditions (green, EGFP ${ }^{+}$neurons; black, EGFP- neurons). Note the evoked responses to every stimulus in the EGFP ${ }^{+}$neuron. 0 , Stratum oriens; $r$, stratum radiatum; $p$, stratum pyramidale. B1, Targeted cell-attached recordings from an EGFP ${ }^{+}$cell in response to 10 alveus stimulations in control ACSF ( 2 consecutive trains of stimulation separated by $30 \mathrm{~s}$; open arrows mark each stimulation within a TS train). Note that each stimulation within the train drove the cell to fire an action potential (1 spike is indicated by a large filled arrow; enlarged in $\boldsymbol{B 2}$ ). Average spike probability as a function of stimulus number is plotted on the bottom histogram. Error bars indicate SEMs. B2, Representative superimposed cell-attached recordings of action potentials evoked in response to a train of 10 consecutive alveus stimulations in an EGFP ${ }^{+}$cell $(10 \mathrm{~Hz})$. Latency histogram of the recorded cell is plotted below. C, Bar graphs of the mean calcium response probability (fraction of trains within a stimulation protocol that evoked a suprathreshold calcium response; antidromic stimulation was discarded) in response to TS protocol in EGFP ${ }^{+}$(dark green; $n=21$ ) and EGFP ${ }^{-}$(black; $n=884$ ) cells. Note that mean action potential probability (fraction of stimuli evoking an action potential) assessed by targeted cell-attached recordings in EGFP ${ }^{+}$cells $(n=10$; light green) is similar to the calcium response probability measured in the same cell population. The calcium response probability was significantly higher in EGFP ${ }^{+}$cells compared with EGFP ${ }^{-}$cells (Mann-Whitney test, $\left.{ }^{* * *} p<0.001\right)$.

blocked by the sodium channel blocker TTX ( $1 \mu \mathrm{M} ; n=3$ movies, 259 cells; data not shown). Evoked calcium events could be triggered by either an EPSP or antidromic activation producing action potential firing. Antidromic activation resulted from the direct electrical stimulation of the cell membrane and therefore was not blocked by antagonists of ionotropic synaptic transmission. Antidromically evoked calcium events were discarded from the analysis (see Materials and Methods). We quantified the response of imaged neurons to TS protocols by calculating a "calcium response probability" per imaged neuron that is the fraction of TS trains within the course of the experiment that evoked a detected calcium event in the cell (i.e., a calcium signal above the 5\% DF/F detection threshold). Cells that could never be activated during the TS protocol were discarded. Such calcium response probability thus indirectly quantifies the fraction of TS trains evoking at least one action potential. We found that, in control conditions, calcium response probability was $100 \pm 0 \%$ in all EGFP $^{+}$cells $(n=21)$ and $27 \pm 7 \%$ in EGFP-negative $\left(\mathrm{EGFP}^{-}\right)$cells ( $n=884$ neurons, 7 movies; $p<0.001$ ) (Fig. 2). Response probability in $\mathrm{EGFP}^{-}$cells was not different be- tween layers $(39 \pm 7 \%$ in stratum pyramidale vs $24 \pm 11 \%$ in stratum oriens and $28 \pm 11 \%$ in stratum radiatum; $p>$ 0.1 , Mann-Whitney test; $n=8$ movies) but was always significantly lower than in $\mathrm{EGFP}^{+}$cells, most of which were located in stratum oriens. We next performed targeted cell attached recordings from $\mathrm{EGFP}^{+}$cells to measure action potential firing in these neurons. In keeping with imaging experiments, EGFP ${ }^{+}$ cells fired at least one action potential in response to each TS train $(99 \pm 1 \%$ of trains evoked at least one action potential; $n=98$ trains, $10 \mathrm{EGFP}^{+}$neurons) (Fig. 2). Furthermore, these experiments showed that $\mathrm{EGFP}^{+}$cells also reliably followed every single stimulation within trains because spike probability for the first stimulus was $77 \pm 25 \%$ and remained stable during the train (spike probability for the fifth stimulus was $84 \pm 22 \% ; n=8 \mathrm{EGFP}^{+}$neurons; $p=$ 0.53 , Mann-Whitney test). Spike latency (measured as the delay between the stimulus artifact and the action potential onset $)$ was $11.2 \pm 1.9 \mathrm{~ms}\left(n=10 \mathrm{EGFP}^{+}\right.$ cells) (Fig. 2). The spike jitter was relatively large, suggesting that the response was driven by an EPSP with slow kinetics ( $1.7 \mathrm{~ms}$ jitter; $n=8 \mathrm{EGFP}^{+}$cells) (Pouille and Scanziani, 2004). We conclude that CA1 stratum oriens EGFP ${ }^{+}$neurons respond to synaptic stimulations at theta frequency. This property distinguishes them from other CA1 neurons. Because KA-Rs represent a significant contribution to the glutamatergic influx received by CA1 stratum oriens interneurons (Cossart et al., 1998, 2002), we next asked whether KA-Rs could mediate such selective synaptically evoked response.

\section{KA-Rs are major contributors to the spontaneous} glutamatergic currents received by $\mathrm{O}$-LM cells

As a first step, we quantified the contribution of KA-Rs to glutamatergic transmission in different cell types without pharmacological manipulation. We performed whole-cell voltage-clamp recordings of glutamatergic activity in $13 \mathrm{EGFP}^{+}$and $33 \mathrm{EGFP}^{-}$ interneurons in the CA1 stratum oriens using biocytin-filled electrodes. Six CA1 stratum oriens interneurons were also recorded in wild-type mice (Table 1).

$\mathrm{EPSC}_{\mathrm{KA}}$ can be distinguished from $\mathrm{EPSC}_{\mathrm{AMPA}}$ solely on the basis of their kinetics profile (Cossart et al., 2002; Epsztein et al., 2005). We thus determined the kinetic properties of EPSCs and focused on action potential-independent mEPSCs, which represent quantal events that are particularly suited for kinetic analysis (Cossart et al., 2002; Epsztein et al., 2005). Miniature EPSCs were recorded in the presence of the sodium channel blocker TTX (1 $\mu \mathrm{M}$ ) at the reversal potential for GABAergic currents ( $V_{\text {hold }},-60$ $\mathrm{mV}$ ). The rise and decay time constants were calculated for each miniature event. mEPSCs amplitude, frequency, and charge were also quantified (Table 2). We included only interneurons that could be fully morphologically identified (Fig. 3$)(n=40)$ : O-LM 
Table 1. Morphological distribution of EGFP ${ }^{+}$and EGFP ${ }^{-}$CA1 stratum oriens interneurons

\begin{tabular}{|c|c|c|c|c|c|}
\hline & All & $\mathrm{EGFP}^{+}$ & $\mathrm{EGFP}^{-}$ & Wild type & $\left(\% \mathrm{EGFP}^{+}\right)$ \\
\hline 0 -LM & 32 & 12 & 16 & 4 & 50 \\
\hline $0-P$ & 12 & 0 & 11 & 1 & 0 \\
\hline 0-Tri & 3 & 0 & 3 & 0 & 0 \\
\hline $0-B i$ & 7 & 0 & 7 & 0 & 0 \\
\hline $0-0$ & 4 & 1 & 2 & 1 & 4 \\
\hline $0-S / B P$ & 14 & 11 & 3 & 0 & 46 \\
\hline Total & 72 & 24 & 42 & 6 & \\
\hline
\end{tabular}

0 -Tri, Stratum oriens interneurons with a trilaminar axonal arborization; $0-0$, stratum oriens interneurons with an axon innervating only the stratum oriens.

Table 2. Properties of $m E P S C s$, EPSC $_{K A}$, EEPSC $_{A M P A}$, and fraction of $m E P S C_{K A}$ in CA1 stratum oriens interneurons

\begin{tabular}{lcccc}
\hline & $0-\mathrm{LM}$ & $0-\mathrm{P}$ & $0-\mathrm{Bi}$ & $0-\mathrm{S} / \mathrm{BP}$ \\
\hline mEPSC decay (ms) & 6.1 & 3.6 & 2.8 & 5.4 \\
mEPSC $_{\text {KA }}$ decay (ms) & 8.8 & 6.6 & 7.4 & 9.9 \\
mEPSC $_{\text {AMPA }}$ decay (ms) & 2.4 & 2.4 & 2.9 & 3.0 \\
mEPSC $_{\text {KA }}(\%)$ & 88.3 & 42.6 & 37.6 & 57.3 \\
mEPSC frequency (Hz) $_{\text {mEPSC amplitude (pA) }}$ & 2.2 & 2.5 & 2.8 & 2.2 \\
mEPSC charge (pA/ms) $_{n}$ & 10.7 & 11.8 & 13.5 & 11.0 \\
& 90.7 & 67.7 & 68.7 & 81.8 \\
\hline
\end{tabular}

$97 \times 103 \mathrm{~mm}(600 \times 600 \mathrm{dpi})$.

cells ( $n=20)$; O-P cells ( $n=11)$ (Harris et al., 1985; Kosaka et al., 1985; Maccaferri et al., 2000; McBain and Fisahn, 2001), O-Bi cells $(n=5)$ (Sik et al., 1995), and O-S/BP interneurons $(n=4)$ (Sik et al., 1995; Gulyas et al., 2003) (see Materials and Methods). As detailed in our previous studies (Cossart et al., 2002; Epsztein et al., 2005), mEPSC $_{\mathrm{KA}}$ were identified in each recording based on their kinetics and pharmacological properties (Fig. 3) (see Materials and Methods) to determine their relative contribution to the global miniature glutamatergic influx for each cell type. We found that the decay time constants of averaged mEPSCs in O-LM cells were slower $(6.1 \pm 0.2 \mathrm{~ms} ; n=20 ; p<0.001)$ than those in O-P $(3.6 \pm 0.5 \mathrm{~ms} ; n=11)$ and $\mathrm{O}-\mathrm{Bi}(2.8 \pm 0.3 \mathrm{~ms} ; n=$ $5)$ interneurons. In O-S/BP interneurons, there was a larger variability of kinetics between cells $(5.4 \pm 1.3 \mathrm{~ms} ; n=4)$. The difference in decay times was unlikely to result from different KA-R or AMPA-R subunit compositions between interneuron types because decay times for $\mathrm{mEPSC}_{\mathrm{KA}}$ or $\mathrm{mEPSC}_{\mathrm{AMPA}}$ were not significantly different between cell types (Table 2).

We then determined the relative contribution of KA-Rmediated synaptic currents in different types of interneurons. We found that mEPSC $_{\mathrm{KA}}$ accounted for a large majority of the total quantal glutamatergic influx in the O-LM cell type as opposed to other neurons. Thus, mEPSC $_{\mathrm{KA}}$ represented $88 \pm 2 \%(n=20)$ (Fig. 3 ) of the total quantal glutamatergic activity on O-LM neurons but less than half ( $43 \pm 6 \%, n=11$ and $38 \pm 6 \%, n=5$ ) (Fig. 3 ) of the activity in $\mathrm{O}-\mathrm{P}$ and $\mathrm{O}-\mathrm{Bi}$ interneurons, respectively. In $\mathrm{O}-\mathrm{S} / \mathrm{BP}$ neurons, there was also less contribution of KA-R to miniature activity $(57 \pm 7 \% ; n=4)$ although the values were more variable most likely attributable to the weaker reliability of the morphological characterization of this cell type (see above).

We conclude that synaptic KA-Rs are differentially distributed among CA1 stratum oriens interneurons and represent the major source of the ongoing glutamatergic influx received by O-LM cells.

\section{A selective processing of postsynaptic glutamatergic} responses evoked at theta via KA-Rs in O-LM cells

We next asked whether the differential distribution of KA-Rs among interneuron subtypes could account for the reliable activation of $\mathrm{EGFP}^{+}$cells during TS protocols. We first isolated KA$\mathrm{R}$-mediated responses in the presence of NMDA and $\mathrm{GABA}_{\mathrm{A}}$ receptor antagonists (control conditions: response probability in $\mathrm{EGFP}^{+}$and $\mathrm{EGFP}^{-}$cells was not significantly different from drug-free saline), relying on their resistance to AMPA-R antagonists (GYKI 52466 at $100 \mu \mathrm{M}$ or NBQX at $1 \mu \mathrm{M}$ ) (Paternain et al., 1995; Bureau et al., 1999) (see Materials and Methods) and blockade by the mixed AMPA/KA-R antagonist CNQX (50 $\mu \mathrm{M})$. Imaging experiments indicated that, in the presence of AMPA-R antagonists, calcium response probability was significantly higher in $\mathrm{EGFP}^{+}$than $\mathrm{EGFP}^{-}$neurons $(58 \pm 17$ vs $9 \pm 6 \%$, respectively; $n=8 \mathrm{EGFP}^{+}$cells, $n=884$ neurons imaged; $p<$ $0.05)$. Furthermore, blockade of AMPA-Rs significantly reduced response probability in $\mathrm{EGFP}^{-}$cells relative to control in all layers (reduction to $33 \pm 4 \%$ of control; $p<0.05$ ) (Fig. 4), whereas probability in $\mathrm{EGFP}^{+}$cells was also reduced but not significantly (to $65 \pm 18 \%$ of control; $p>0.05$ ) (Fig. 4). However, relative changes in probability resulting from AMPA-R blockade were not significantly different when comparing EGFP ${ }^{+}$and EGFP ${ }^{-}$ cells ( $p=0.3$, Mann-Whitney test). Indeed, two subpopulations of EGFP ${ }^{+}$neurons could be distinguished in conditions in which synaptic excitation was provided only by KA-Rs because calcium response probability remained unchanged relative to control in half of EGFP ${ }^{+}$cells $\left(n=8 \mathrm{EGFP}^{+}\right.$cells). The amplitude of the evoked calcium transient in KA-R-responsive $\mathrm{EGFP}^{+}$neurons was reduced, but not significantly, in the presence of blockers, to $72 \pm 29 \%$ of control values $\left(n=8 \mathrm{EGFP}^{+}\right.$cells; $\left.p>0.05\right)$, suggesting that fewer action potentials were triggered when blocking AMPA receptors and decreasing network excitability or when KA-Rs were partially blocked by AMPA-R antagonists (Castillo et al., 1997). Evoked calcium responses in GYKIresponsive $\mathrm{EGFP}^{+}$neurons were fully suppressed when KA-Rs were blocked by further adding CNQX $(50 \mu \mathrm{M})$ to the perfusion saline. Therefore, synaptically evoked responses presenting a KA-R pharmacology (i.e., resistant to AMPA, NMDA, and $\mathrm{GABA}_{\mathrm{A}}$ blockers but suppressed by CNQX) were selectively present in the $\mathrm{EGFP}^{+}$cell population.

Second, to determine the involvement of KA-Rs in more physiological conditions, we used a functional antagonist for KA-Rs (SYM 2081 at $10 \mu \mathrm{M}$ ) (Zhou et al., 1997; Li et al., 1999; DeVries, 2000; Cossart et al., 2002; Epsztein et al., 2005) that did not affect the global level of spontaneous activity in the network (fraction of active cells in control, $46 \pm 5$ vs $40 \pm 6 \%$ after SYM 2081; $n=899$ imaged neurons; data not shown; $p>0.05)$. The calcium response probability was not significantly affected by SYM 2081 in EGFP $^{-}$neurons from all hippocampal layers (98 \pm $5 \%$ of control in the presence of SYM 2081; $n=899$ neurons; $p>$ 0.05 ) (Fig. 4). In contrast, in the $\mathrm{EGFP}^{+}$cell population, calcium response probability was significantly decreased in the presence of SYM 2081 (to $53 \pm 14 \%$ of control after SYM 2081; $n=11$ neurons; $p<0.05$ ) (Fig. 4). This further confirmed that approximately half of the $\mathrm{EGFP}^{+}$cell population responds to the TS through the activation of KA-Rs (KA-responsive $\mathrm{EGFP}^{+}$cells: $\mathrm{EGFP}^{+}$neurons with $>80 \%$ calcium response probability in GYKI 52466 and $<20 \%$ probability in SYM 2081, i.e., $51 \%$ of $\mathrm{EGFP}^{+}$cells), whereas the other half responds through AMPA-Rs (AMPA-responsive $\mathrm{EGFP}^{+}$cells: $\mathrm{EGFP}^{+}$neurons with $<20 \%$ calcium response probability in GYKI 52466 and $>80 \%$ probability in SYM 2081, i.e., $41 \%$ of EGFP ${ }^{+}$cells; $\left.n=25\right)$. 
A

1

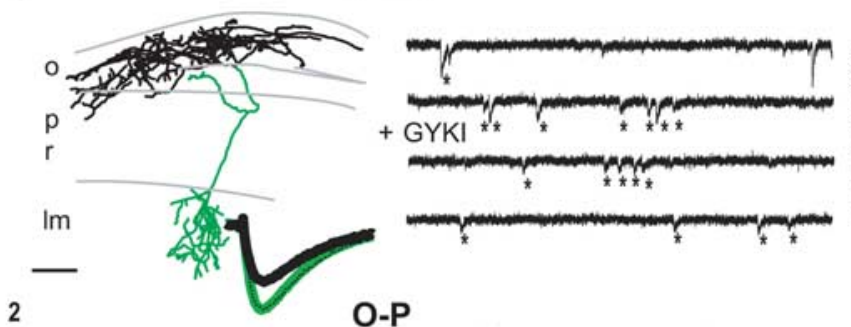

2
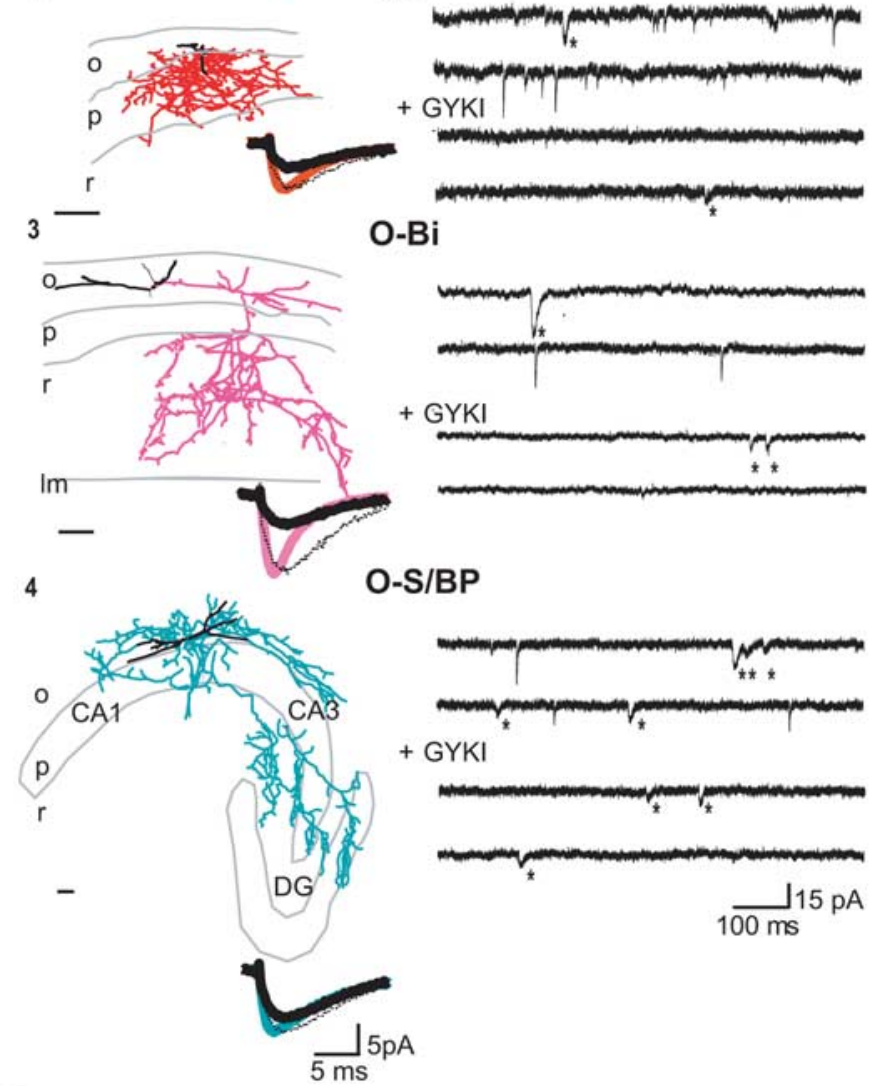

B

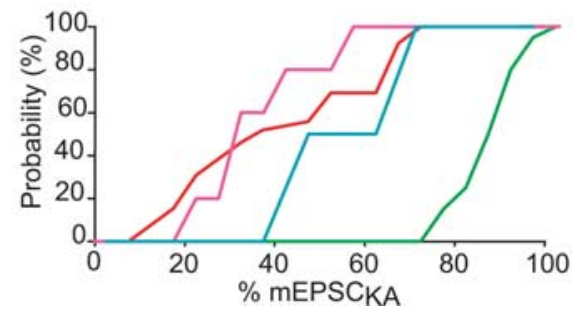

Figure 3. Differential contribution of KA-Rs to glutamatergic transmission in different types of stratum oriens interneurons. A1, Left, Neurolucida three-dimensional reconstruction of a biocytin-filled EGFP ${ }^{+} / 0$-LM (green). The axon is indicated in color. 0 Stratum oriens; $p$, stratum pyramidale; r, stratum radiatum; Im, stratum lacunosum moleculare. Scale bar, $100 \mu \mathrm{m}$. Inset, Averaged mEPSCs from an 0-LM cell (color trace, control conditions, i.e., in the presence of TTX at $1 \mu \mathrm{m}$, bicuculline at $10 \mu \mathrm{M}$, and D-APV at $40 \mu \mathrm{m}$; black, with AMPA-R antagonist GYKI 52466 at $100 \mu \mathrm{m}$; dashed, normalized traces). Middle, Voltage-clamp recordings $\left(V_{\mathrm{h}}\right.$ of $\left.-60 \mathrm{mV}\right)$ of miniature EPSCs recorded in the cell illustrated at the left in the presence of TTX at $1 \mu \mathrm{M}$, bicuculline at $10 \mu \mathrm{m}$, and D-APV at $40 \mu \mathrm{m}$. mEPSC $\mathrm{KA}_{\mathrm{A}}$ can be isolated pharmacologically as events resistant to AMPA-R antagonists (GYKI 52466 at $100 \mu \mathrm{M})$ and blocked by the AMPA/KA-R antagonist (CNQX at $50 \mu \mathrm{m}$; data not shown). In control conditions, two types of $m E P S C$ can be distinguished based on the time course of their decay: fast and slow $\left(^{*}\right)$ EPSCs. mEPSC ${ }_{K A}$ correspond to slow events $\left(^{*}\right)$. Right, Cumulative probability plot of the distribution of individual mEPSC decays ( $n=200$ events) in the illustrated cell in control conditions (color trace) and in the presence of GYKI 52466 (100 $\mu \mathrm{m}$; black). Note that plots overlap in the 0-LM cell. $\boldsymbol{A 2}$, Same as $\boldsymbol{A} \boldsymbol{1}$ for a EGFP ${ }^{-} / 0$-P (red). $\boldsymbol{A}$ 3, Same as $\boldsymbol{A} \boldsymbol{1}$ for an EGFP ${ }^{-} / 0-B i$ (pink) interneuron. $\boldsymbol{A 4}$, Same as $\boldsymbol{A} \boldsymbol{1}$ for an EGFP ${ }^{+} / 0-\mathrm{S} / \mathrm{BP}$ neuron (blue). DG, Dentate gyrus. $B$, Cumulative probability plots of the distribution of the averaged fraction of $m E P S C_{K A}$ for 0 -LM (green; $n=20$ ), 0-P (red; $n=11$ ), 0 -Bi cells (pink), and 0-S/BP (blue; $n=4$ ) cells. Note that 0 -LM cells have the highest percentage of KA-R-mediated events.
To further confirm that $10 \mathrm{~Hz}$ stimulation of the alveus specifically triggered a suprathreshold KA-R-mediated synaptic response in a subpopulation of somatostatin-containing neurons, we performed current-clamp recordings in $\mathrm{EGFP}^{+}$neurons. In the presence of AMPA, NMDA, and $\mathrm{GABA}_{\mathrm{A}}$ receptor antagonists, an EPSP $_{\mathrm{KA}}$ could be evoked by TS in a majority of $\mathrm{EGFP}^{+}$cells $(71 \%)$ with an amplitude decreased to $37 \pm 10 \%$ of control values ( $n=14 \mathrm{EGFP}^{+}$cells). Such EPSP $_{\mathrm{KA}}$ could lead to action potential firing with a latency comparable with that obtained in cell-attached recordings ( $10.1 \pm 2.3 \mathrm{~ms} ; n=5$ cells) (see Fig. 7 ). We specifically performed cell-attached recordings to quantify KA-R-mediated action potential probability in more reliable experimental conditions. A KA-Rmediated action potential firing could be evoked in approximately half of EGFP ${ }^{+}$ neurons (40\%), and action potential probability was $68 \pm 21 \%\left(n=10 \mathrm{EGFP}^{+}\right.$cells $)$ (Fig. 5). Both current-clamp and cellattached responses were blocked by further addition of CNQX $(50 \mu \mathrm{M})$, validating that they were mediated by KA-Rs. To further confirm the role of KA-Rs in evoked glutamatergic responses in $\mathrm{EGFP}^{+}$ neurons, we next performed currentclamp and cell-attached recordings in these cells in the presence of the KA-R functional antagonist SYM 2081 (see Materials and Methods). Current-clamp recordings in $\mathrm{EGFP}^{+}$cells revealed that application of SYM 2081 reduced the amplitude of the evoked EPSP to $44 \pm$ $11 \%$ of control $(n=12 ; p<0.05)$. The effect of SYM 2081 on EPSP amplitude was dependent on the $\mathrm{EGFP}^{+}$cell type as revealed by post hoc morphological identification of recorded neurons. Indeed, application of SYM 2081 completely abolished the evoked EPSP in $\mathrm{EGFP}^{+} / \mathrm{O}-\mathrm{LM}$ neurons (to $10 \pm 10 \%$ of control; $n=5$ ) (see Fig. 7), whereas the response was relatively preserved (to $73 \pm 9 \%$ of control; $n=7$; $p<0.01$ ) (see Fig. 7) in $\mathrm{EGFP}^{+} /$non$\mathrm{O}-\mathrm{LM}$ neurons such as O-S/BP interneurons. Remaining responses were fully blocked by further addition of GYKI 52466 $(100 \mu \mathrm{M}), \mathrm{D}-\mathrm{APV}(40 \mu \mathrm{M})$, and bicuculline $(10 \mu \mathrm{M})$. Finally, application of SYM 2081 abolished evoked action potential firing recorded in current-clamp mode in 66\% of $\mathrm{EGFP}^{+}$neurons $\left(n=3 \mathrm{EGFP}^{+}\right.$cells $)$ (see Fig. 7).

We conclude that KA-R activation selectively provides a subpopulation of $\mathrm{EGFP}^{+}$cells that includes O-LM cells, with the property to follow reliably theta stimulation protocols. Finally, to further 
determine the cell type specificity of KA-R-responsive cells, we filled cells with biocytin at the end of the imaging experiments and histologically processed the slices. We found that all KA-R-responsive stratum oriens interneurons belonged to the O-LM cell type $(n=4)$ (Fig. 6), whereas AMPA-R-responsive stratum oriens $\mathrm{EGFP}^{+}$interneurons were O-S/BP neurons $(n=5)$ (Fig. 6). Interestingly, we recorded from a few $\mathrm{EGFP}^{-}$cells that followed TS through KA-Rs and found that they all corresponded to O-LM neurons $(n=3)$. This also confirms that EGFP labels only a subset of O-LM cells as reported previously (Oliva et al., 2000). However, such $\mathrm{EGFP}^{-} / \mathrm{O}-\mathrm{LM}$ neurons are likely to constitute a minority of imaged stratum oriens $\mathrm{EGFP}^{-}$neurons because the overall response probability to $\mathrm{TS}$ of $\mathrm{EGFP}^{-}$cells in this region was not significantly different from that in other layers. Finally, we also recorded from $\mathrm{EGFP}^{-}$interneurons that did follow TS but not through KA-Rs; these cells were either O-P or O-Bi interneurons $(n=2)$ (Fig. 6). We conclude that KA-R activation selectively provides O-LM cells with the ability to reliably follow theta stimulation protocols. We next asked for the cellular mechanisms underlying such specificity.

Efficient EPSP $_{\mathrm{KA}^{-}}$spike coupling in OLM cells stimulated at theta frequency Several presynaptic and postsynaptic mechanisms could drive O-LM cells to fire at $10 \mathrm{~Hz}$ in response to afferent theta inputs, including, as previously reported, a short-term facilitation of the glutamatergic drive impinging on this cell type (Ali and Thomson, 1998; Maccaferri, 2005) or a summation of slow EPSP $_{\mathrm{KA}}$ (Castillo et al., 1997; Cossart et al., 1998; Frerking et al., 1998; Frerking and Ohliger-Frerking, 2002).

To discriminate between these hypotheses, because both phenomenon are frequency dependent, we recorded evoked EPSPs in $\mathrm{EGFP}^{+}$neurons during a sequence of trains of 10 stimuli at 1, 3, 10, 50, and $100 \mathrm{~Hz}$, repeated once every $30 \mathrm{~s}$. Frequency facilitation was assessed by measuring the amplitude ratio of the second and the last (10th) EPSP relative to the first one $\left(\operatorname{EPSP}_{2-1}\right.$ and $\left.\operatorname{EPSP}_{10-1}\right)$ across all frequencies while EPSP summation was visually inspected. At $10 \mathrm{~Hz}$, the response of $\mathrm{EGFP}^{+} / \mathrm{O}-\mathrm{LM}$ neurons was, on average, stable between stimulation trials $(10 \mathrm{~Hz}$; $\mathrm{EPSP}_{2-1}, 130 \pm 19 \%$ EPSP $_{10-1}, 130 \pm 19 \% ; n=5 ; p>0.05$ ) (Fig. 7 ). We found a significant facilitation of the response only for stimulation rates above $50 \mathrm{~Hz}$ in $\mathrm{EGFP}^{+} / \mathrm{O}$-LM cells, whereas short-term facilitation could already be observed at $10 \mathrm{~Hz}$ in
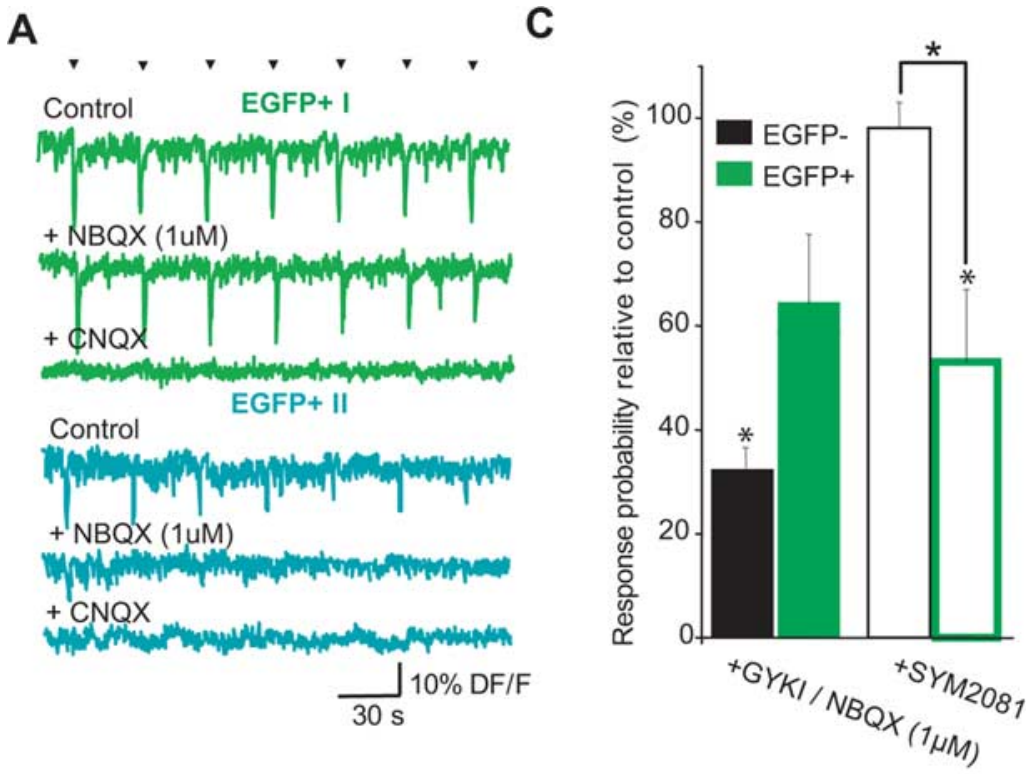

B

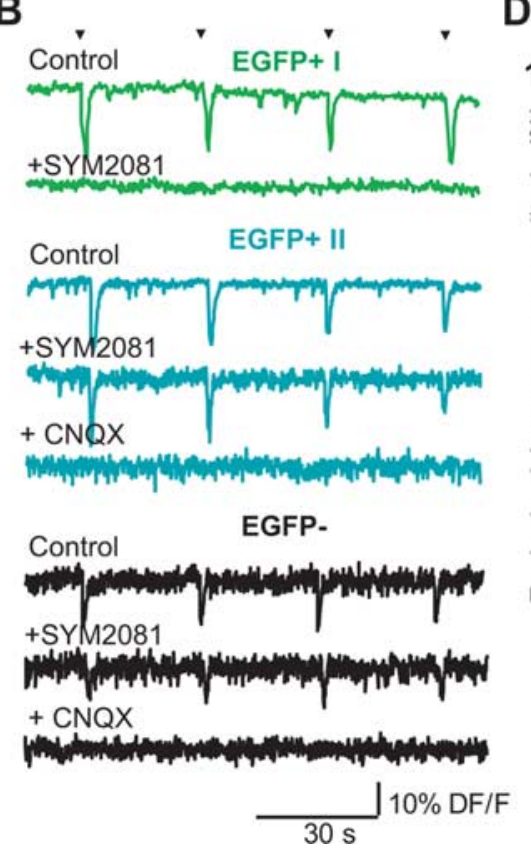

12

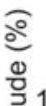

2

EGFP+1

TS 1 TS 4

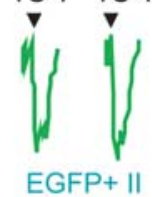

TS 1 TS 4

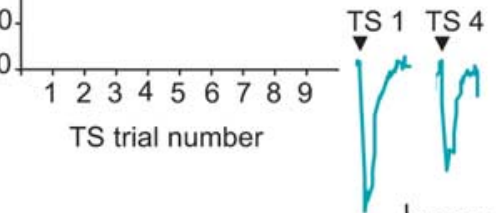

${ }_{5 \mathrm{~s}} 10 \% \mathrm{DF} / \mathrm{F}$

Figure 4. A selective processing of theta stimulation influx via KA-Rs in a subpopulation of EGFP ${ }^{+}$cells. $\boldsymbol{A}$, Fluorescence traces in response to the TS protocol from representative examples of the two populations of EGFP ${ }^{+}$neurons (green, EGFP + I; blue, EGFP + II) in bicuculline at $10 \mu \mathrm{m}$ and D-APV at $40 \mu \mathrm{m}$ (control), when adding a KA-Rantagonist (NBQXat $1 \mu \mathrm{m}$ ) and the AMPA/KA-Rantagonist (CNQX at $50 \mu \mathrm{m}$ ); arrows mark the stimuli. Note that the EGFP+ I neuron (green) responds to all stimuli in the presence of the AMPA-R antagonist, whereas the EGFP ${ }^{+} \|$neuron (blue) responds only to the first stimulus. $B$, Same as in $A$ but in a EGFP ${ }^{+} I_{\text {, EGFP }}{ }^{+} \|$, and EGFP ${ }^{-}$ interneuron (black), in drug-free ACSF (control), when adding a KA-R antagonist (SYM 2081 at $10 \mu \mathrm{M}$ ) and the AMPA/KA-R antagonist (CNQX at $50 \mu \mathrm{m}$ ). Note that the response in the EGFP ${ }^{+}$I neuron (green) was significantly reduced in the presence of SYM 2081, although it was not significantly affected in both other cell types. $\boldsymbol{C}$, Bar histograms show the averaged changes in calcium response probability to the $10 \mathrm{~Hz}$ stimulation relative to control conditions (D-APV at $40 \mu \mathrm{m}$ and bicuculline at $10 \mu \mathrm{m}$ ), in KA-R-mediated conditions (i.e., in the presence of GYKI52466 at $100 \mu \mathrm{m}$ or NBQX at $1 \mu \mathrm{m}$; filled bars), and in the presence of a KA-R antagonist (SYM 2081 at $10 \mu \mathrm{m}$; open bars) in EGFP ${ }^{-}$(black) and EGFP ${ }^{+}$(green) cells. ${ }^{*} p<0.01$ when comparing relative change with control and between populations. D1, Graph illustrates the averaged amplitudes of the calcium responses evoked by nine successive TS protocols as a function of time (i.e., TS trial number) in KA-R-responsive EGFP ${ }^{+}$cells (EGFP + I, green) and in AMPA-R responsive EGFP ${ }^{+}$neurons (EGFP + II, blue). Error bars indicate SEMs. D2, Representative examples of the calcium responses evoked by the first and the fourth TS trial in an 0-LM cell (green) and an 0-S/BP cell (blue). Arrows indicate TS time.

non-O-LM/EGFP ${ }^{+}$cells, including O-S/BP neurons $\left(\right.$EPSP $_{2-1}$,

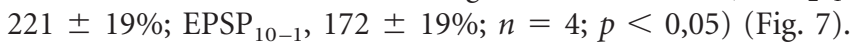
Accordingly, EPSP $_{\mathrm{KA}}$ s, recorded in the presence of GYKI 52466, neither facilitated nor summated at $10 \mathrm{~Hz}\left(\mathrm{EPSP}_{2-1}, 141 \pm 14 \%\right.$; 
A

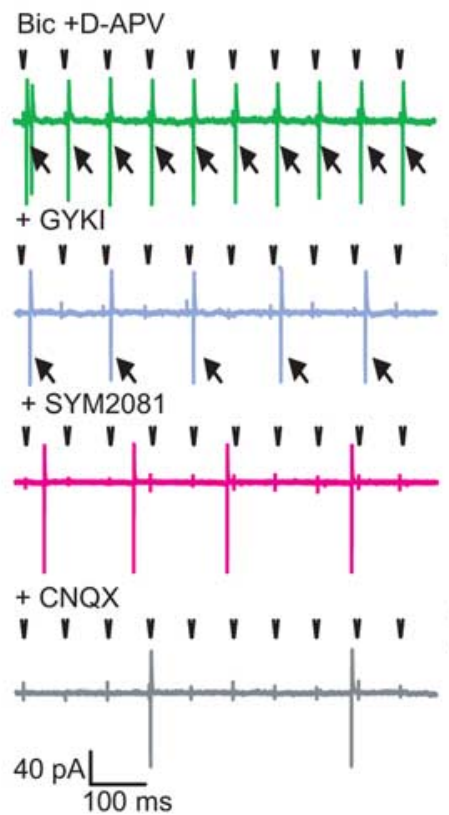

B
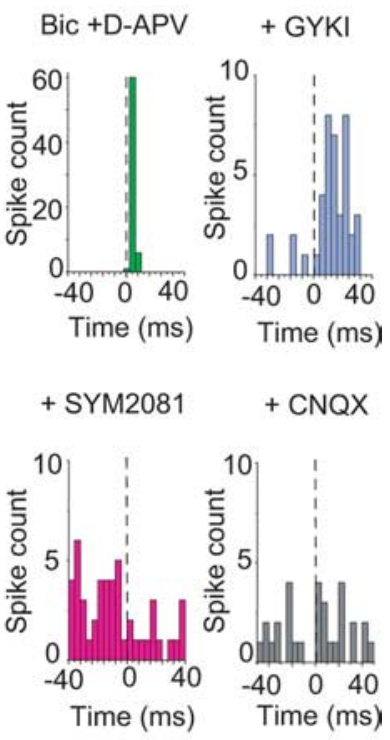

C



Figure 5. Targeted cell-attached recordings show that $\mathrm{EGFP}^{+}$cells can respond to theta stimulation through KA-Rs. A, Cell-attached recordings from an EGFP ${ }^{+}$cell in response to 10 alveus stimulations at $10 \mathrm{~Hz}$ (open arrows) in the presence of bicuculline (Bic; $10 \mu \mathrm{M}$ ) and D-APV (40 $\mu \mathrm{m}$; green). Action potentials (large arrows, time-locked spikes) were still evoked when the AMPA-R antagonist GYKI 52466 (100 $\mu$ m; blue) was added but not in the presence of the KA-R antagonist SYM 2081 (10 $\mu$ m; pink) or the AMPA/KA-R antagonist CNQX (50 $\mu$ m; gray). $\boldsymbol{B}$, Peristimulus time histograms (same recordings as in $\boldsymbol{A}$; dashed line indicates time of stimulation) constructed from 10 series of 10 alveus stimulations at $10 \mathrm{~Hz}$. C, Bar graphs of averaged spike probability in cell-attached recordings from EGFP ${ }^{+}$cells in control $(n=10)$, in D-APV plus bicuculline $(n=10)$, and when adding GYKI $52466(n=4)$ and SYM $2081(n=3)$. Error bars indicate SEMs.

EPSP $\left._{10-1}, 122 \pm 14 \% ; n=7\right)$. Therefore, KA-Rs mediate a constant and reliable postsynaptic response when activated at $10 \mathrm{~Hz}$ in O-LM cells without significant facilitation or summation, which are observed at higher stimulation rates (Fig. 7). Interestingly, because O-S/BP neurons followed TS through a facilitating AMPA-R-mediated response, we hypothesized that these properties would not enable this cell type to fire in a steady way across different trains of stimulation. To test this hypothesis, we compared the stability of the calcium response between successive TS trials in KA-responsive and AMPA-responsive $\mathrm{EGFP}^{+}$neurons and found that the amplitude of the evoked calcium event progressively declined in AMPA- but not KA-responsive EGFP ${ }^{+}$ neurons (Fig. 4D). The decrease started being significant for the third trial. This indicated that the response to TS was more stable across time for KA-responsive $\mathrm{EGFP}^{+}$neurons than for AMPAresponsive $\mathrm{EGFP}^{+}$neurons.

Because modeling studies predict that the frequency of network oscillations depends in part on the time course of synaptic currents in interneurons (Traub et al., 1996; Wang and Buzsaki, 1996; Fuchs et al., 2001), we next hypothesized that the specific EPSP $_{\mathrm{KA}}$ kinetics could partly provide the O-LM interneuron type with their selective activation at theta. In keeping with this hypothesis, the decay time constants of averaged EPSPs in O-LM cells were indeed slower $(40 \pm 9 \mathrm{~ms} ; n=5 ; p<0.05)$ than those in $\mathrm{EGFP}^{+} /$non-O-LM cells $(22 \pm 3 \mathrm{~ms} ; n=8 ; p<0.05)$, whereas input resistance was comparable in both cell types $(139 \pm 11$ and $145 \pm 10 \mathrm{M} \Omega$, respectively; $p>0.1$ ). There was no statistical difference in the evoked EPSP decay time between control conditions and after adding GYKI 52466 in O-LM neurons (38 \pm 7 $\mathrm{ms}$ in GYKI 52466; $n=9$ cells; $p>0.05$ ) (Fig. 7). We indirectly tested the hypothesis that slower EPSPs could drive any cell type to fire at theta using a compound (CX546 at $200 \mu \mathrm{M}$ ) that, as reported previously (Pouille and Scanziani, 2004; Xia and Arai, 2005), slows the deactivation and desensitization of AMPA-Rs. Responses to TS were monitored at the network level using calcium imaging and at the cell level using current-clamp recordings. CA1 was surgically isolated from CA3 to avoid contamination from polysynaptic events that could be generated in the latter region, and control conditions were recorded in the presence of D-APV $(40 \mu \mathrm{M})$ only in the ACSF. We confirmed that CX546 application significantly increased the decay time constant of averaged evoked EPSPs in CA1 pyramidal cells and stratum oriens interneurons (to $166 \pm 19$ and $208 \pm 51 \%$ of control values, respectively; $n=5$ pyramidal cells and 7 interneurons; $p<0.05$ ) (Fig. 8). Current-clamp recordings at resting membrane potential in the presence of CX546 showed that slower EPSPs tended to summate (Fig. 8). This could increase the probability of action potential firing because $48 \pm 13$ and $49 \pm 17 \%$ of TS trains could evoke at least one spike in the presence of CX546 in pyramidal cells $(n=5)$ and interneurons $(n=7)$, respectively, compared with $6 \pm 6$ and $10 \pm 5 \%$ trains in control. However, firing was not reliably evoked by each stimulation (as measured in O-LM cells) because spike probability per train was $13 \pm 4$ and $30 \pm 20 \%$ in the presence of CX546 in pyramidal cells $(n=5)$ and interneurons $(n=7)$ compared with $1 \pm 2$ and $2 \pm 1 \%$ in control conditions. In keeping with this observation, we observed a small but not significant increase in the amplitude of the evoked calcium response to the TS in the presence of CX546 (to $125 \pm 12 \%$ of control values; $n=7$ movies, 1245 cells; $p>0.5$, Mann-Whitney test) but no change in the fraction of cells displaying a $100 \%$ calcium response probability ( $18 \pm 3 \%$ in control vs $16 \pm 4 \%$ in CX546; $n=7$ movies, 1245 cells; $p>0.5$, Mann-Whitney test) (Fig. $8 A$ ). We conclude that EPSP kinetics alone cannot account for the ability of the O-LM cells to reliably follow theta stimulation and that intrinsic properties specific to this particular cell type (Maccaferri and McBain, 1996; Martina et al., 2000; Pike et al., 2000; Saraga et al., 2003; Gloveli et al., 2005; Maccaferri, 2005; Lawrence et al., 2006a,b,c) are likely to be involved in the reliable $\mathrm{EPSP}_{\mathrm{KA}}-$ spike coupling at $10 \mathrm{~Hz}$. Future studies are required to investigate the nature of this coupling.

In summary, these results show both at the cellular and network level a specific and reliable processing of theta glutamatergic afferent inputs by KA-Rs in O-LM interneurons.

\section{Discussion}

Using fast two-photon imaging to analyze electrically evoked calcium dynamics from hundreds of cells, we show that O-LM cells 
are the only stratum oriens interneuronal subtype that processes glutamatergic inputs exclusively through KA-Rs. Relying on the imaging data, we performed electrophysiological recordings showing unequivocally that $\mathrm{EGFP}^{+} / \mathrm{O}-\mathrm{LM}$ neurons are selectively activated by theta stimuli by means of KA-R-mediated EPSPs. Functionally, we show that this unique postsynaptic property endows O-LM cells with the ability to follow reliably input stimulation at theta frequency.

Somatostatin-containing interneurons are activated by theta frequency stimulation protocols

In imaging experiments, we found that applying a TS protocol to the alveus resulted in the preferential activation of stratum oriens $\mathrm{EGFP}^{+}$cells as opposed to pyramidal or other interneurons in all layers of the CA1 region. The detected calcium response resulted from the opening of voltage-gated calcium channels attributable to synaptically mediated firing because of the following: (1) the fast kinetics and small amplitude of the evoked signals indicate calcium entry through action potential firing rather than other mechanisms for intracellular calcium accumulation [such as calcium release from intracellular stores (Rozas et al., 2003)]; (2) evoked calcium signals were abolished by blocking synaptic transmission or action potential firing; and (3) the TS protocol evoked action potential firing and EPSPs in $\mathrm{EGFP}^{+}$cells.

An increase in membrane excitability attributable to the inhibition of the slow afterhyperpolarization currents $\left(I_{\mathrm{AHP}}\right)$ by synaptically activated KA-Rs could also contribute to the calcium signal (Cherubini et al., 1990; Melyan et al., 2002; Ruiz et al., 2005). However, such effect is unlikely because (1) it should also involve CA1 pyramidal cells (Ruiz et al., 2005), (2) increased excitability would be abolished within the time window of our TS protocol (Ruiz et al., 2005), (3) current-clamp recordings do not indicate an increase in the firing of interneurons after repeated stimuli trials, and (4) the calcium response amplitude remained unchanged during TS in $\mathrm{EGFP}^{+} / \mathrm{O}-\mathrm{LM}$ cells, indicating that the number of spikes evoked was constant (Smetters et al., 1999). We conclude that the TS protocol used here induced synapse-driven action potential firing in $\mathrm{EGFP}^{+}$cells.

Stratum oriens somatostatin-containing neurons comprise O-LM (Katona et al., 1999), O-S/BP (Gulyas et al., 2003), and O-Bi (Maccaferri et al., 2000; Martina et al., 2000; Losonczy et al., 2002) neurons. Most biocytin-filled EGFP ${ }^{+}$cells in our sample data were

A

C

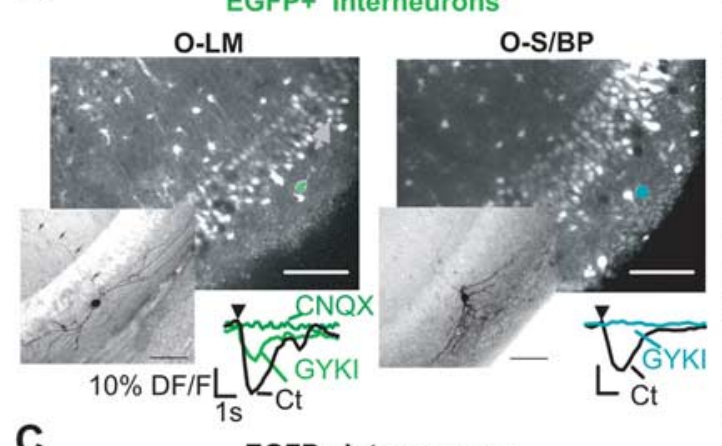

EGFP- Interneurons
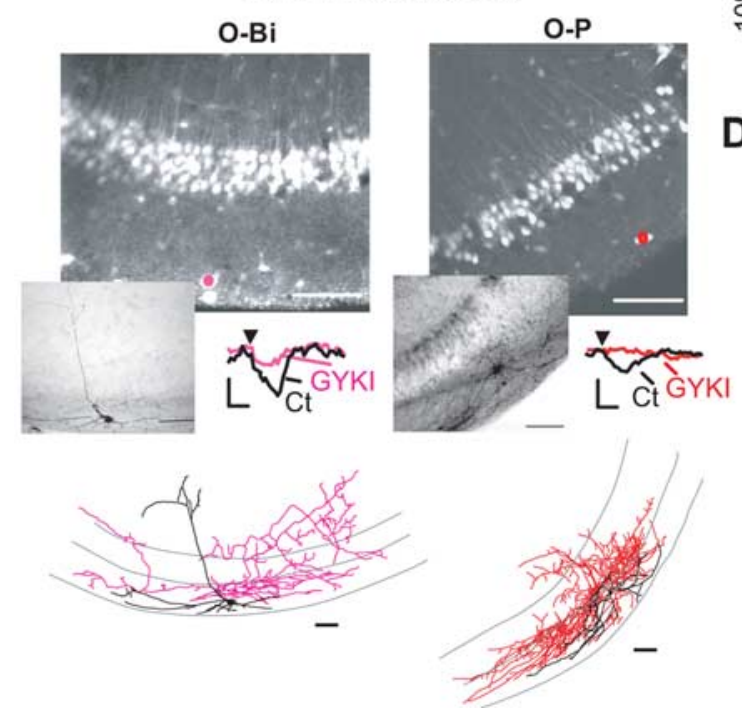

Figure 6. Kainate receptor-mediated calcium response in 0-LM but not in other cells. Two-photon calcium imaging in the CA1 region from EGFP mouse hippocampal slices at postnatal day 14 (excitation wavelength, $780 \mathrm{~nm}$; time resolution, $145 \mathrm{~ms} /$ frame). $\mathrm{EGFP}^{+}$neurons were identified within the same slice (excitation wavelength, $900 \mathrm{~nm}$ ). Slices were stimulated $(10 \mathrm{~Hz}$ stimulation protocol, TS) in control and in KA-R-mediated conditions (in the presence of AMPA-R, NMDA-R, and GABA ${ }_{A}-R$ antagonists; GYKI 52466 at $100 \mu \mathrm{M}, \mathrm{D}-\mathrm{APV}$ at $40 \mu \mathrm{m}$, and bicuculline at $10 \mu \mathrm{m}$ ). At the end of each experiment, targeted neurons were patched, filled with biocytin, and identified morphologically. $A$, Calcium fluorescence images superimposed with the EGFP image (in green or blue) indicate the presence of an EGFP ${ }^{+}$cell in the stratum oriens for each movie. These neurons were identified post hoc as an 0 -LM cell (left) and a septum/back-projecting neuron ( $0-\mathrm{S} / \mathrm{BP}$ neuron; right) as shown by the photomicrographs of the biocytinfilled cells. Arrows in the left photomicrograph indicate the 0 -LM cell axon. Scale bar, $100 \mu \mathrm{m}$. Bottom traces are averaged evoked calcium responses by the TS protocol in 0-LM cells $(n=4)$ and $0-\mathrm{S} / \mathrm{BP}$ cells $(n=5)$, in control (Ct, black) and in KA-R-mediated conditions (i.e., in the presence of the AMPA-R antagonist GYKI 52466 at $100 \mu \mathrm{m}$; light green or blue). Responses were fully blocked in the presence of CNQX (dark green). Same scale in 0-S/BP neuron as in 0 -LM neuron. $B$, Calcium fluorescence traces from an 0-LM (green), an 0-S/BP neuron (blue), and an EGFP ${ }^{-}$neuron (black, the illustrated cell is marked with a gray arrow in $\boldsymbol{A}$ ) imaged in control [D-APV at $40 \mu \mathrm{m}$ and bicuculline (Bic) at $10 \mu \mathrm{m}$ ], in KA-R-mediated conditions (i.e., when adding GYKI 52466 at $100 \mu \mathrm{M})$, and in the presence of the AMPA/KA-R antagonist CNQX (50 $\mu \mathrm{M})$. Note that all illustrated cells responded to the TS protocol in control, whereas only the 0 -LM cell showed responses in KA-R-mediated conditions that were blocked in CNQX. C, Left two-photon calcium fluorescence image: the EGFP ${ }^{-}$cell marked with a pink dot was identified post hoc as an 0-Bi interneuron (photomicrograph illustrates the biocytin-filled cell; see also Neurolucida reconstruction below). Averaged evoked calcium responses by the TS protocol in control (black) and in KA-R-mediated conditions (see $\boldsymbol{B}$; same scale as in $\boldsymbol{A}$ ). A small response remained in KA-R-mediated conditions ( 1 of 4 trains of 10 stimuli; pink). It was blocked by CNQX. Right, Two-photon calcium fluorescence image; the EGFP ${ }^{-}$cell marked with a red dot was identified post hoc as an 0-P interneuron (photomicrograph illustrates the biocytin-filled cell; see also Neurolucida reconstruction below). Averaged evoked calcium responses by the TS protocol in control (Ct, black) and in KA-R-mediated conditions (GYKI 52466, red). Bottom, Neurolucida reconstructions of the 0-P and 0-Bi interneurons imaged above (axons in color: pink, 0-Bi; red, 0-P). Scale bar, $100 \mu \mathrm{m}$. D, Bar graphs of the KA-R-mediated response probability (see $\boldsymbol{B}$ ) in EGFP ${ }^{-}$neurons (black; $n=430$ ), 0 -LM neurons (green; $n=4$ ), and $0-\mathrm{S} / \mathrm{BP}$ neurons (blue; $n=$ 5). ${ }^{* * *} p<0.0010$-LM cells vs $0-\mathrm{S} / \mathrm{BP}$ and EGFP ${ }^{-}$neurons.

O-LM cells (Oliva et al., 2000) but also included O-S/BP interneurons (Maccaferri et al., 2000; Losonczy et al., 2002). The distinction between O-S/BP and O-LM cells was unequivocal because, even with a cut axon, an O-LM cell presents a characteristic spiny dendritic arbor. We have not isolated the type of fibers activated during 
A

1

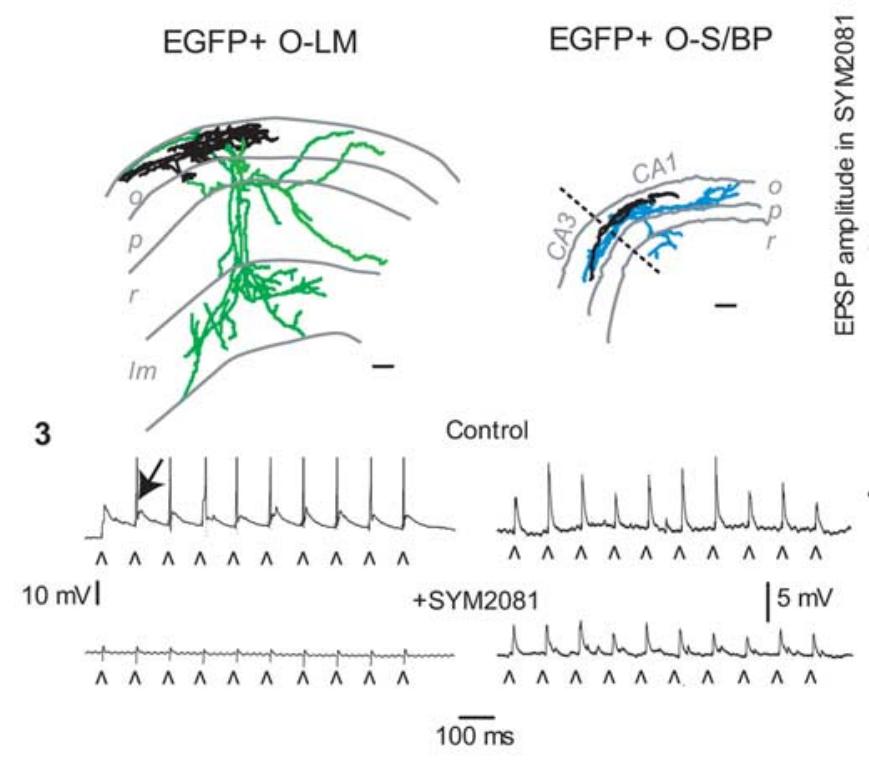

B

1
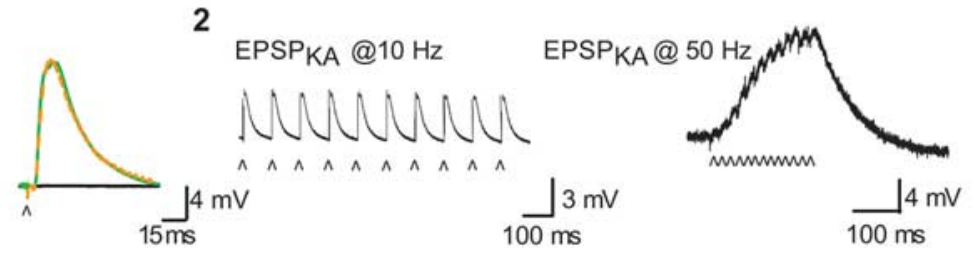

C 1

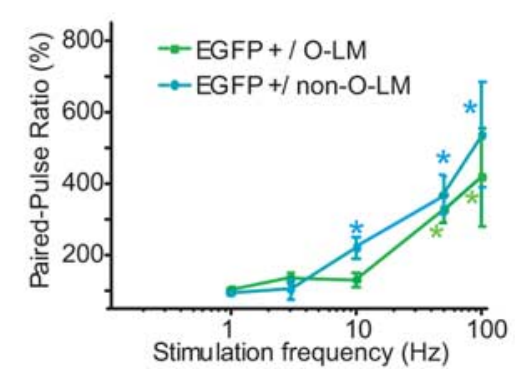

2

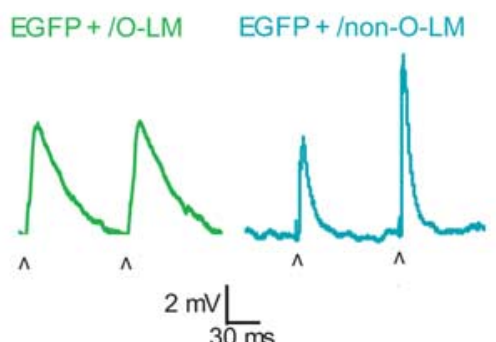

Figure 7. Frequency- and cell-type-dependent plasticity of the evoked EPSP in EGFP ${ }^{+}$neurons. A1, Neurolucida reconstructions of two typical EGFP-positive neurons, one 0-LM cell (left, green axon) and one 0-S/BP interneuron (right, axon in blue). 0, Stratum oriens; $p$, stratum pyramidale; $r$, stratum radiatum; Im, stratum lacunosum moleculare. Scale bar, $100 \mu \mathrm{m}$. A2, Current-clamp recordings at resting

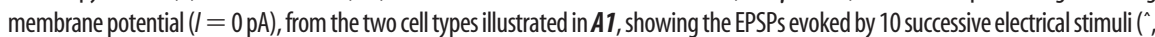
$10 \mathrm{~Hz}$ ) in control conditions (i.e., in D-APV at $40 \mu \mathrm{m}$ and bicuculline at $10 \mu \mathrm{M}$ ) and in the presence of the functional antagonist for KA-Rs (SYM 2081 at $10 \mu \mathrm{m}$ ). Note that the EPSPs evoked in control in the EGFP ${ }^{+} / 0$-LM cell were suprathreshold (arrow indicates an action potential), whereas spikes could not be evoked in the illustrated 0-S/BP neuron. A3, Evoked EPSPs are blocked in the presence of SYM 2081 in EGFP ${ }^{+} / 0$-LM cells ( $n=5$; green bar; ${ }^{*} p<0.05$ ), indicating that they are KA-R mediated, whereas they are only partially affected in non-0-LM/EGFP ${ }^{+}$cells $(n=5)$. EPSP amplitude is measured relative to control values. Error bars indicate SEMs. A4, Latency histogram of the spikes evoked in current clamp in the EGFP ${ }^{+} / 0-L M$ cell illustrated in A3. B1, Example of an evoked EPSP recorded in current clamp $\left(V_{\text {rest }} I=0 \mathrm{pA}\right)$ in an 0 -LM/EGFP + cell in the presence of $\mathrm{D}-\mathrm{APV}(40 \mu \mathrm{m})$ and bicuculline (10 $\mu \mathrm{m}$; green) and when adding GYKI 52466 (100 $\mu \mathrm{m}$; dashed orange). Both traces overlap, indicating that the evoked EPSP in control conditions was KA-R mediated (EPSP ${ }_{K A}$ ). The EPSP ${ }_{K A}$ was blocked after addition of CNQX (50 $\mu$ M; black). B2, EPSP KA $^{S}$ are not plastic for repetitive $10 \mathrm{~Hz}$ stimulation (left traces) but show a significant summation/facilitation for shorter stimulation intervals ( $50 \mathrm{~Hz}$; right), as illustrated by the current-clamp recordings in the presence of AMPA-R, NMDA-R, and GABA $-R$ antagonists (GYKI 52466 at $100 \mu \mathrm{m}$, D-APV at $40 \mu \mathrm{m}$, and bicuculline at $10 \mu \mathrm{m}$ ). ^ indicates the time of stimulation. C1, Graph illustrates paired-pulse ratio (fraction of the EPSP amplitudes evoked by 2 successive stimuli) as a function of stimulation frequency in $\mathrm{EGFP}^{+} / 0$-LM cells (green) and in EGFP ${ }^{+} /$non- 0 -LM cells (blue). ${ }^{*} p<0.05$, significant facilitation of the response. $(2$, Representative current-clamp recordings from EPSPs evoked by $10 \mathrm{~Hz}$ stimulation in the two EGFP ${ }^{+}$populations mentioned in C1. Note the difference in EPSP kinetics in EGFP ${ }^{+} / 0$-LM cells and non-0-LM cells. The open arrow indicates time of stimulation. stimulation. However, because the stimulation electrode was placed in the alveus and direct activation of dendrites was excluded, it is likely that Schaffer or CA1 collaterals were stimulated. For O-LM cells, the latter alternative is more probable because these cells are exclusively innervated by CA1 collaterals (Wittner et al., 2006) and because direct antidromic stimulation of CA1 pyramidal cells could be verified while imaging.

Cellular basis for the selective activation of O-LM/EGFP ${ }^{+}$interneurons at theta stimulation frequencies

O-LM cells are remarkably tuned to operate at theta frequencies spontaneously (Maccaferri and McBain, 1996), during current injections (Pike et al., 2000), pharmacologically induced oscillations in vitro (Hajos et al., 2004; Gloveli et al., 2005), as well as during local theta oscillations in vivo (Klausberger et al., 2003). We established the uniqueness of this property in the CA1 region by imaging all neurons simultaneously and morphologically identifying reliably responsive cells. Although intrinsic conductances, muscarinic receptor activation, and slow membrane time constants (Maccaferri and McBain, 1996; Ali and Thomson, 1998; Martina et al., 2000; Pike et al., 2000; Losonczy et al., 2002; Saraga et al., 2003; Pouille and Scanziani, 2004; Gloveli et al., 2005; Maccaferri, 2005; Lawrence et al., 2006a,b,c) are also involved in the intrinsic resonance peak of O-LM cells at theta frequencies, the activation of postsynaptic KA-Rs is instrumental to their ability to follow theta synaptic stimulation. First, the selective blockade of KA-Rs by SYM 2081 (Zhou et al., 1997; Li et al., 1999; DeVries, 2000; Cossart et al., 2002; Epsztein et al., 2005) specifically blocks the calcium response to TS in O-LM/EGFP ${ }^{+}$ neurons. Second, TS reliably evoked a GYKI 52466-resistant/CNQX-blocked calcium response in O-LM cells. Third, activation of KA-Rs in $\mathrm{EGFP}^{+}$neurons drives postsynaptic depolarization and action potential firing; both responses were blocked by SYM 2081 only in O-LM/EGFP ${ }^{+}$. Fourth, almost $90 \%$ of mEPSCs recorded in O-LM cells were KA-R mediated; voltage-clamp experiments provide a quantification of the involvement of KA-Rs in the absence of pharmacological manipulation. It is difficult to isolate a KAR-mediated process based solely on pharmacological agents because specific antagonists for AMPA-Rs also partially block KA-Rs (Castillo et al., 1997), whereas the functional KA-R antagonist SYM 2081 works in a usedependent manner (DeVries, 2000). Finally, current-clamp recordings showed that blocking AMPA-Rs did not affect the decay of the EPSPs in O-LM cells. 
A

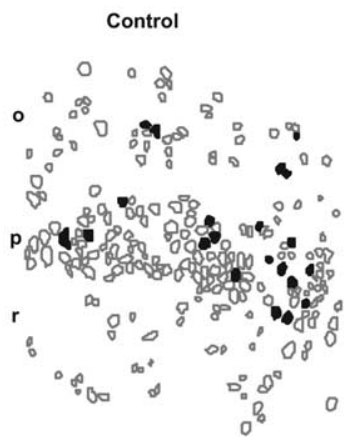

$B_{1}$

CA1 Interneuron

2

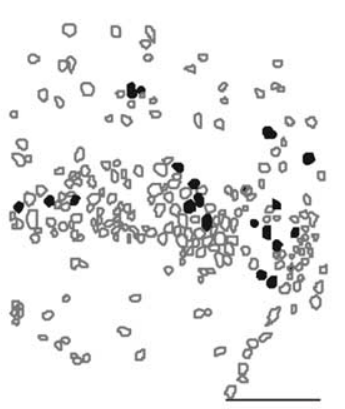

CA1 Pyramidal cell
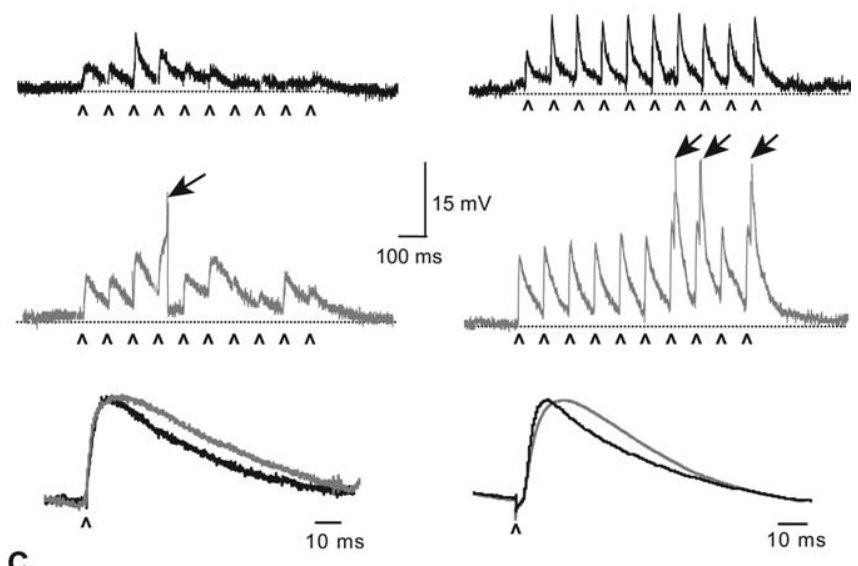

C

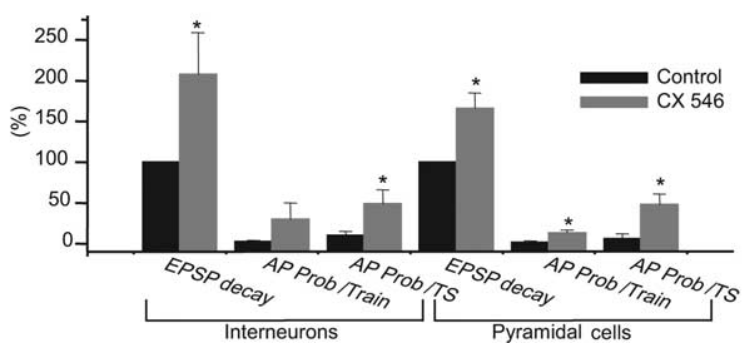

Figure 8. EPSP kinetics alone do not determine the response to theta stimulation protocols. $\boldsymbol{A}$, Contour maps indicate an example of the distribution of cells responding with $100 \%$ calcium response probability to TS protocols in the CA1 region (black filled contours) in control (D-APV at $40 \mu \mathrm{m}$; left) and in the presence of $\mathrm{CX} 546$ (200 $\mu \mathrm{m}$; right) to slow the kinetics of EPSP ${ }_{\mathrm{AMPA}} \cdot 0$, Stratum oriens; $p$, stratum pyramidale; r, stratum radiatum. Scale bar, $100 \mu \mathrm{m}$. The fraction of cells responding reliably to all trains of stimulation is not increased in the presence of CX546. B1, Current-clamp recording at resting membrane potential $\left(V_{\text {rest }}\right.$ of approximately $-65 \mathrm{mV}$ ) of EPSPs evoked by a TS train in control (D-APV at $40 \mu \mathrm{m}$; top, black) and in the presence of CX546 (200 $\mu \mathrm{m}$; middle, gray) in a CA1 stratum oriens interneuron. Open arrows indicate time of stimulation. Action potential firing (filled arrow, truncated) could be evoked in XX546 conditions. Summation of the EPSPs is clearly visible in the presence of CX546 (baseline level is indicated by dotted lines). Bottom traces are averaged evoked EPSPs during a TS in control (black) and in CX546 (gray) recorded at $V_{\text {rest }}$ in a CA1 stratum oriens interneuron. Note that XX546 significantly increased the EPSP decay times. Open arrows indicate stimulation. B2, Same as $\boldsymbol{B} 1$ but in a CA1 pyramidal cell. C, Bar histogram plots averaged values of evoked EPSP decay times, action potential probability per train (AP Prob/Train, i.e., averaged number of action potentials evoked within 1 train of 10 stimuli at $10 \mathrm{~Hz}$ ), and action potential probability per TS protocol (AP Prob/TS, i.e., fraction of trains within the TS protocol evoking at least 1 action potential), for CA1 stratum oriens interneurons (left; $n=7$ ) and pyramidal cells (right; $n=5$ ) in control (D-APV at $40 \mu \mathrm{m}$; black) and when adding CX546 (200 $\mu \mathrm{m}$; gray). Error bars indicate SEMs. * $p<0.05$.

Therefore, we establish that KA-Rs transmit theta inputs selectively to O-LM cells. An almost exclusive processing of glutamatergic inputs through KA-Rs is in agreement with our previous study in rat slices (Cossart et al., 2002). Glutamate uncaging experiments have also established that most O-LM cells show KA-R-mediated currents, with a small minority expressing responses restricted to a few dendritic spots (Yang et al., 2006, 2007). AMPA-Rs also contributed to the uncaging response, but such results are difficult to interpret attributable to the likely contribution of extrasynaptic receptors under these experimental conditions. Unfortunately, most studies examining synaptic transmission onto O-LM cells did not differentiate between AMPA-R and KA-R contributions (Ali and Thomson, 1998; Losonczy et al., 2002; Pouille and Scanziani, 2004; Biro et al., 2005; Biro and Nusser, 2005) but reported slower EPSP kinetics in these cells (Ali and Thomson, 1998; Losonczy et al., 2002; Pouille and Scanziani, 2004).

We show that KA-Rs not only convey but also partly mediate the reliable activation of $\mathrm{O}-\mathrm{LM}$ cells within this frequency range. Indeed, short-term plasticity of the response in O-LM cells is excluded because facilitation of the evoked EPSP was not observed between 1 and $10 \mathrm{~Hz}$. Summation of the EPSP was not recorded either given the relatively fast kinetics of evoked EPSP $_{\mathrm{KA}}$ in O-LM cells compared with the stimulation interval and with the slower kinetics of EPSP $\mathrm{KA}_{\text {in }}$ in other cell types such as CA3 pyramidal neurons ( $\sim 100 \mathrm{~ms}$ ) (Castillo et al., 1997; Cossart et al., 2002; Frerking and Ohliger-Frerking, 2002). Facilitating/summating EPSCs in O-LM cells have been reported for stimulus intervals shorter than $100 \mathrm{~ms}$, in agreement with our findings (Ali and Thomson, 1998; Losonczy et al., 2002; Pouille and Scanziani, 2004). Our results indicate that summation of glutamatergic inputs does not translate into reliable EPSP-spike coupling efficiency at theta frequency because prolonging the decay of the EPSP $_{\mathrm{AMPA}}$ to mimic an EPSP $\mathrm{KA}_{\mathrm{A}}$ using CX546 (Pouille and Scanziani, 2004) increased firing probability but did not activate non$\mathrm{O}-\mathrm{LM} / \mathrm{CA} 1$ neurons as reliably as O-LM cells. Therefore, the efficient $\mathrm{EPSP}_{\mathrm{KA}}-$ spike coupling for $10 \mathrm{~Hz}$ inputs is specific for the O-LM cell type, and the exact intrinsic membrane properties responsible for such property remain to be determined. The strong sodium channel density expressed by O-LM cells may facilitate KA-R-driven action potential generation (Martina et al., 2000). Furthermore, the combination of theta bandpass resonant properties, significantly longer AHPs, and slower membrane time constants (Gloveli et al., 2005) should also attribute O-LM cells with a greater propensity to fire in the theta frequency range.

In contrast to O-LM cells, calcium imaging and patch-clamp recordings revealed that non-O-LM/EGFP ${ }^{+}$neurons, such as $\mathrm{O}$ $\mathrm{S} / \mathrm{BP}$ cells, were activated by TS stimulation but that such response was not KA-R mediated. Indeed, evoked calcium events and EPSPs were blocked by GYKI 52466 and resistant to SYM 2081, in agreement with the fact that KA-Rs mediated half of the quantal glutamatergic drive received by these neurons, a significantly minor contribution than in O-LM cells, rather comparable with that in O-P or O-Bi cells. Finally, we found that, unlike $\mathrm{O}-\mathrm{LM}$ cells, non-O-LM/EGFP ${ }^{+}$neurons presented facilitating responses at $10 \mathrm{~Hz}$. Comparable facilitation was reported recently for Schaffer collateral synapses onto CA1 stratum radiatum somatostatin interneurons (Sun and Dobrunz, 2006). Such facilitation might account for the fact that this $\mathrm{EGFP}^{+}$subpopulation was also attributed a $100 \%$ calcium response probability for TS protocols in control conditions. It is, however, possible that short-term plasticity will not allow this cell type to fire in a steady way as attested by the evolution of the evoked calcium response as a function of time. In any case, future studies are required to examine the cellular mechanisms accounting for the partial ability of O-S/BP cells to follow TS.

In conclusion, we show that O-LM cells are the only CA1 
neuronal subtype that reliably processes glutamatergic inputs received with theta frequency primarily through postsynaptic KARs. KA-R-mediated theta band activation in neurons is fully predictive of their O-LM phenotype. Intriguingly, the specific inhibition of glutamate receptor subtype 5-containing KA-Rs, the subtype principally expressed in CA1 stratum oriens interneurons (Cossart et al., 1998), was shown recently to affect hippocampal theta oscillations in freely moving animals (Huxter et al., 2007). This finding strongly suggests that the postsynaptic specificity of O-LM cells described here might be the cellular basis for the generation of theta oscillatory activity in behaving animals.

\section{References}

Ali AB (2003) Involvement of post-synaptic kainate receptors during synaptic transmission between unitary connections in rat neocortex. Eur J Neurosci 17:2344-2350.

Ali AB, Thomson AM (1998) Facilitating pyramid to horizontal oriensalveus interneurone inputs: dual intracellular recordings in slices of rat hippocampus. J Physiol (Lond) 507:185-199.

Ben Ari Y, Cossart R (2000) Kainate, a double agent that generates seizures: two decades of progress. Trends Neurosci 23:580-587.

Biro AA, Nusser Z (2005) Synapse independence breaks down during highly synchronous network activity in the rat hippocampus. Eur J Neurosci 22:1257-1262.

Biro AA, Holderith NB, Nusser Z (2005) Quantal size is independent of the release probability at hippocampal excitatory synapses. J Neurosci 25:223-232.

Bureau I, Bischoff S, Heinemann SF, Mulle C (1999) Kainate receptormediated responses in the CA1 field of wild-type and GluR6-deficient mice. J Neurosci 19:653-663.

Buzsaki G (2002) Theta oscillations in the hippocampus. Neuron 33:325-340.

Castillo PE, Malenka RC, Nicoll RA (1997) Kainate receptors mediate a slow postsynaptic current in hippocampal CA3 neurons. Nature 388:182-186.

Cherubini E, Rovira C, Ben-Ari Y, Nistri A (1990) Effects of kainate on the excitability of rat hippocampal neurones. Epilepsy Res 5:18-27.

Cobb SR, Buhl EH, Halasy K, Paulsen O, Somogyi P (1995) Synchronization of neuronal activity in hippocampus by individual GABAergic interneurons. Nature 378:75-78.

Cossart R, Esclapez M, Hirsch JC, Bernard C, Ben-Ari Y (1998) GluR5 kainate receptor activation of interneurons increases tonic GABAergic inhibition in pyramidal cells. Nat Neurosci 1:470-478.

Cossart R, Epsztein J, Tyzio R, Becq H, Hirsch J, Ben Ari Y, Crepel V (2002) Quantal release of glutamate generates pure kainate and mixed AMPA/ kainate EPSCs in hippocampal neurons. Neuron 35:147-159.

Cossart R, Aronov D, Yuste R (2003) Attractor dynamics of network UP states in the neocortex. Nature 423:283-288.

Cossart R, Ikegaya Y, Yuste R (2005) Calcium imaging of cortical networks dynamics. Cell Calcium 37:451-457.

Cossart R, Petanjek Z, Dumitriu D, Hirsch JC, Ben-Ari Y, Esclapez M, Bernard C (2006) Interneurons targeting similar layers receive synaptic inputs with similar kinetics. Hippocampus 16:408-420.

DeVries SH (2000) Bipolar cells use kainate and AMPA receptors to filter visual information into separate channels. Neuron 28:847-856.

Epsztein J, Represa A, Jorquera I, Ben-Ari Y, Crepel V (2005) Recurrent mossy fibers establish aberrant kainate receptor-operated synapses on granule cells from epileptic rats. J Neurosci 25:8229-8239.

Frerking M, Ohliger-Frerking P (2002) AMPA receptors and kainate receptors encode different features of afferent activity. J Neurosci 22:7434-7443.

Frerking M, Malenka RC, Nicoll RA (1998) Synaptic activation of kainate receptors on hippocampal interneurons. Nat Neurosci 1:479-486.

Freund TF, Buzsáki G (1996) Interneurons of the hippocampus. Hippocampus 6:347-470.

Fuchs EC, Doheny H, Faulkner H, Caputi A, Traub RD, Bibbig A, Kopell N, Whittington MA, Monyer H (2001) Genetically altered AMPA-type glutamate receptor kinetics in interneurons disrupt long-range synchrony of gamma oscillation. Proc Natl Acad Sci USA 98:3571-3576.

Gillies MJ, Traub RD, LeBeau FE, Davies CH, Gloveli T, Buhl EH, Whitting- ton MA (2002) A model of atropine-resistant theta oscillations in rat hippocampal area CA1. J Physiol (Lond) 543:779-793.

Gloveli T, Dugladze T, Saha S, Monyer H, Heinemann U, Traub RD, Whittington MA, Buhl EH (2005) Differential involvement of oriens/pyramidale interneurones in hippocampal network oscillations in vitro. J Physiol (Lond) 562:131-147.

Gulyas AI, Hajos N, Katona I, Freund TF (2003) Interneurons are the local targets of hippocampal inhibitory cells which project to the medial septum. Eur J Neurosci 17:1861-1872.

Hajos N, Palhalmi J, Mann EO, Nemeth B, Paulsen O, Freund TF (2004) Spike timing of distinct types of GABAergic interneuron during hippocampal gamma oscillations in vitro. J Neurosci 24:9127-9137.

Harris KM, Marshall PE, Landis DM (1985) Ultrastructural study of cholecystokinin-immunoreactive cells and processes in area CA1 of the rat hippocampus. J Comp Neurol 233:147-158.

Huxter JR, Zinyuk LE, Roloff EL, Clarke VR, Dolman NP, More JC, Jane DE, Collingridge GL, Muller RU (2007) Inhibition of kainate receptors reduces the frequency of hippocampal theta oscillations. J Neurosci 27:2212-2223.

Katona I, Acsady L, Freund TF (1999) Postsynaptic targets of somatostatinimmunoreactive interneurons in the rat hippocampus. Neuroscience 88:37-55.

Klausberger T, Magill PJ, Marton LF, Roberts JD, Cobden PM, Buzsaki G, Somogyi P (2003) Brain-state- and cell-type-specific firing of hippocampal interneurons in vivo. Nature 421:844-848.

Kosaka T, Kosaka K, Tateishi K, Hamaoka Y, Yanaihara N, Wu J-Y, Hama K (1985) GABAergic neurons containing CCK-8-like and/or VIP-like immunoreactivities in the rat hippocampus and dendate gyrus. J Comp Neurol 239:420-430.

Lawrence JJ, Grinspan ZM, Statland JM, McBain CJ (2006a) Muscarinic receptor activation tunes mouse stratum oriens interneurones to amplify spike reliability. J Physiol (Lond) 571:555-562.

Lawrence JJ, Saraga F, Churchill JF, Statland JM, Travis KE, Skinner FK, McBain CJ (2006b) Somatodendritic Kv7/KCNQ/M channels control interspike interval in hippocampal interneurons. J Neurosci 26:12325-12338.

Lawrence JJ, Statland JM, Grinspan ZM, McBain CJ (2006c) Cell typespecific dependence of muscarinic signalling in mouse hippocampal stratum oriens interneurones. J Physiol (Lond) 570:595-610.

Lerma J (2003) Roles and rules of kainate receptors in synaptic transmission. Nat Rev Neurosci 4:481-495.

Li P, Wilding TJ, Kim SJ, Calejesan AA, Huettner JE, Zhuo M (1999) Kainate-receptor-mediated sensory synaptic transmission in mammalian spinal cord. Nature 397:161-164.

Losonczy A, Zhang L, Shigemoto R, Somogyi P, Nusser Z (2002) Cell type dependence and variability in the short-term plasticity of EPSCs in identified mouse hippocampal interneurones. J Physiol (Lond) 542:193-210.

Maccaferri G (2005) Stratum oriens horizontal interneurone diversity and hippocampal network dynamics. J Physiol (Lond) 562:73-80.

Maccaferri G, McBain CJ (1996) Long-term potentiation in distinct subtypes of hippocampal nonpyramidal neurons. J Neurosci 16:5334-5343.

Maccaferri G, Roberts JD, Szucs P, Cottingham CA, Somogyi P (2000) Cell surface domain specific postsynaptic currents evoked by identified GABAergic neurones in rat hippocampus in vitro. J Physiol (Lond) 524:91-116.

Martina M, Vida I, Jonas P (2000) Distal initiation and active propagation of action potentials in interneuron dendrites. Science 287:295-300.

McBain CJ, Fisahn A (2001) Interneurons unbound. Nat Rev Neurosci 2:11-23.

Melyan Z, Wheal HV, Lancaster B (2002) Metabotropic-mediated kainate receptor regulation of IsAHP and excitability in pyramidal cells. Neuron 34:107-114.

Mulle C, Sailer A, Swanson GT, Brana C, O'Gorman S, Bettler B, Heinemann SF (2000) Subunit composition of kainate receptors in hippocampal interneurons. Neuron 28:475-484.

Oliva AA, Jiang MH, Lam T, Smith KL, Swann JW (2000) Novel hippocampal interneuronal subtypes identified using transgenic mice that express green fluorescent protein in GABAergic interneurons. J Neurosci 20:3354-3368.

Oren I, Mann EO, Paulsen O, Hajos N (2006) Synaptic currents in anatomically identified CA3 neurons during hippocampal gamma oscillations in vitro. J Neurosci 26:9923-9934. 
Paternain AV, Morales M, Lerma J (1995) Selective antagonism of AMPA receptors unmasks kainate receptor- mediated responses in hippocampal neurons. Neuron 14:185-189.

Pike FG, Goddard RS, Suckling JM, Ganter P, Kasthuri N, Paulsen O (2000) Distinct frequency preferences of different types of rat hippocampal neurones in response to oscillatory input currents. J Physiol (Lond) 529:205-213.

Pouille F, Scanziani M (2004) Routing of spike series by dynamic circuits in the hippocampus. Nature 429:717-723.

Rozas JL, Paternain AV, Lerma J (2003) Noncanonical signaling by ionotropic kainate receptors. Neuron 39:543-553.

Ruiz A, Sachidhanandam S, Utvik JK, Coussen F, Mulle C (2005) Distinct subunits in heteromeric kainate receptors mediate ionotropic and metabotropic function at hippocampal mossy fiber synapses. J Neurosci 25:11710-11718.

Saraga F, Wu CP, Zhang L, Skinner FK (2003) Active dendrites and spike propagation in multi-compartment models of oriens-lacunosum/moleculare hippocampal interneurons. J Physiol (Lond) 552:673-689.

Sik A, Penttonen M, Ylinen A, Buzsaki G (1995) Hippocampal CA1 interneurons: an in vivo intracellular labeling study. J Neurosci 15:6651-6665.

Smetters D, Majewska A, Yuste R (1999) Detecting action potentials in neuronal populations with calcium imaging. Methods 18:215-221.

Somogyi P, Klausberger T (2005) Defined types of cortical interneurone structure space and spike timing in the hippocampus. J Physiol (Lond) 562:9-26

Sun HY, Dobrunz LE (2006) Presynaptic kainate receptor activation is a novel mechanism for target cell-specific short-term facilitation at Schaffer collateral synapses. J Neurosci 26:10796-10807.
Traub RD, Whittington MA, Colling SB, Buzsaki G, Jefferys JG (1996) Analysis of gamma rhythms in the rat hippocampus in vitro and in vivo. J Physiol (Lond) 493:471-484.

Vignes M, Collingridge GL (1997) The synaptic activation of kainate receptors. Nature 388:179-182.

Wang XJ, Buzsaki G (1996) Gamma oscillation by synaptic inhibition in a hippocampal interneuronal network model. J Neurosci 16:6402-6413.

Whittington MA, Traub RD (2003) Interneuron diversity series: inhibitory interneurons and network oscillations in vitro. Trends Neurosci 26:676-682.

Whittington MA, Stanford IM, Colling SB, Jefferys JG, Traub RD (1997) Spatiotemporal patterns of gamma frequency oscillations tetanically induced in the rat hippocampal slice. J Physiol (Lond) 502:591-607.

Wittner L, Henze DA, Zaborszky L, Buzsaki G (2006) Hippocampal CA3 pyramidal cells selectively innervate aspiny interneurons. Eur J Neurosci 24:1286-1298.

Xia YF, Arai AC (2005) AMPA receptor modulators have different impact on hippocampal pyramidal cells and interneurons. Neuroscience 135:555-567.

Yang EJ, Harris AZ, Pettit DL (2006) Variable kainate receptor distributions of oriens interneurons. J Neurophysiol 96:1683-1689.

Yang EJ, Harris AZ, Pettit DL (2007) Synaptic kainate currents reset interneuron firing phase. J Physiol (Lond) 578:259-273.

Zhou LM, Gu ZQ, Costa AM, Yamada KA, Mansson PE, Giordano T, Skolnick P, Jones KA (1997) (2S,4R)-4-methylglutamic acid (SYM 2081): a selective, high-affinity ligand for kainate receptors. J Pharmacol Exp Ther 280:422-427. 